Provided for non-commercial research and education use. Not for reproduction, distribution or commercial use.

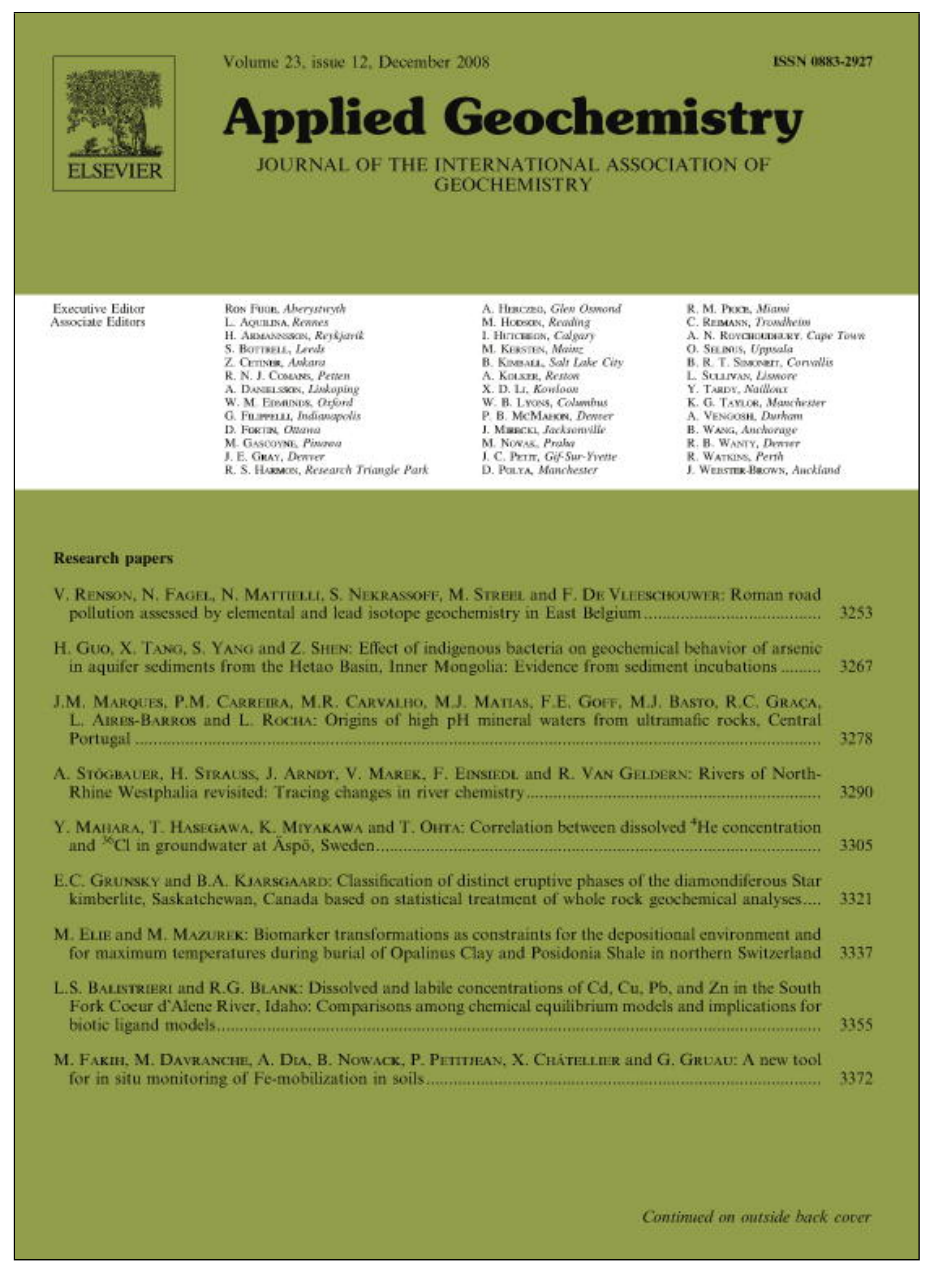

This article appeared in a journal published by Elsevier. The attached copy is furnished to the author for internal non-commercial research and education use, including for instruction at the authors institution and sharing with colleagues.

Other uses, including reproduction and distribution, or selling or licensing copies, or posting to personal, institutional or third party websites are prohibited.

In most cases authors are permitted to post their version of the article (e.g. in Word or Tex form) to their personal website or institutional repository. Authors requiring further information regarding Elsevier's archiving and manuscript policies are encouraged to visit:

http://www.elsevier.com/copyright 


\title{
Roman road pollution assessed by elemental and lead isotope geochemistry in East Belgium
}

\author{
Virginie Renson $^{\mathrm{a}, *}$, Nathalie Fagel ${ }^{\mathrm{a}}$, Nadine Mattielli ${ }^{\mathrm{b}}$, Serge Nekrassoff ${ }^{\mathrm{c}}$, Maurice Streel ${ }^{\mathrm{d}}$, \\ François De Vleeschouwer ${ }^{\mathrm{a}}$ \\ ${ }^{a}$ U.R. Argiles et Paléoclimats, University of Liège, Allée du 6 Août, B18, Sart Tilman, 4000 Liège, Belgium \\ ${ }^{\mathrm{b}}$ Département des Sciences de la Terre et de l'Environnement, Université Libre de Bruxelles, CP160/02, Avenue F.D. Roosevelt, 1050 Brussels, Belgium \\ ' Station Scientifique des Hautes Fagnes 137, Rue de Botrange, 4950 Robertville, Belgium \\ ${ }^{\mathrm{d}}$ U.R.P.P.M., University of Liège, Allée du 6 Aout, B18, Sart Tilman, 4000 Liège, Belgium
}

\section{A R T I C L E I N F O}

\section{Article history:}

Received 8 January 2008

Accepted 27 June 2008

Available online 4 July 2008

Editorial handling by R. Fuge

\begin{abstract}
A B S T R A C T
The ability of inorganic geochemistry to record environmental change and especially human impact has been evidenced by several studies across Europe, especially in peat, where it is possible to record the impact of agriculture, mining and other industries. However, despite the numerous investigations on the impact of ancient human activities such as ore mining and smelting, little attention has been paid to geochemistry as a tool to solve problems of palaeopollution in the surroundings of archaeological sites. This paper presents geochemical evidence of the impact of a possible early Roman road built in SE Belgian peatland. Increased $\mathrm{Zn}$ and $\mathrm{Pb}$ concentrations suggest that $\mathrm{Pb}-\mathrm{Zn}$ ores were transported on the road. Lead isotope analyses suggest that these ores are locally derived, being compatible with those found in the nearby $\mathrm{Pb}-\mathrm{Zn}$ ore deposits from East Belgium. Present results provide direct evidence that East Belgian $\mathrm{Pb}-\mathrm{Zn}$ ores were already being mined during Roman times, i.e. earlier than previously suspected (i.e. 14th century) and that $\mathrm{Zn}$ appears to be relatively immobile here. On a broader scale, it also demonstrates that such an early road already had an impact on the environment in terms of metal pollution. This paper enlarges on the range of possibilities offered by geochemistry in the field of geoarchaeology.
\end{abstract}

(ㄷ) 2008 Elsevier Ltd. All rights reserved.

\section{Introduction}

The Hautes Fagnes plateau (SE-Belgium) consists of a large and discontinuous wetland made of fen, mire and rarely bogs (Fig. 1A). It has provided a key site in studies investigating human occupation and environmental impact in the region since the Celtic civilisation (Remy, 1981; Damblon, 1994; Graillet, 1998; De Vleeschouwer et al., 2007). Interestingly, this area is also located nearby $\mathrm{Pb}-\mathrm{Zn}$ ores that are known to have been mined since the 14th century (Dejonghe and Ladeuze, 1993).

\footnotetext{
* Corresponding author. Present address: Department of Geology, Vrije Universiteit Brussel, Pleinlaan 2, B-1050 Brussels, Belgium. Tel.: +32 2629 3397.

E-mail address: vrenson@vub.ac.be (V. Renson).
}

The Hautes Fagnes plateau is crossed by a $6-\mathrm{km}$ cobbled road, in a NW-SE direction (Fig. 1A), which is now partly covered by peat. Historical (Remy, 1981; Graillet, 1998) and palynological (Dalemans and Streel, 1986) data suggest that it was used as a thoroughfare up to the 13th century although the age of its construction, function and its intended route have always been a matter of debate (e.g. Corbiau, 1981a,b; Dalemans and Streel, 1986).

The cobbled road crossing the Hautes Fagnes is recorded in several historical texts and the archaeological remains were discovered in 1768 (see Nekrassoff, 1993). The first detailed description of the road was made by Bastin (1934), who discovered a multi-layered wooden structure which was thought to form the foundation for the cobblestones on the waterlogged peat (Fig. 1B). Such a structure is not found where the road is crossing non-peaty 

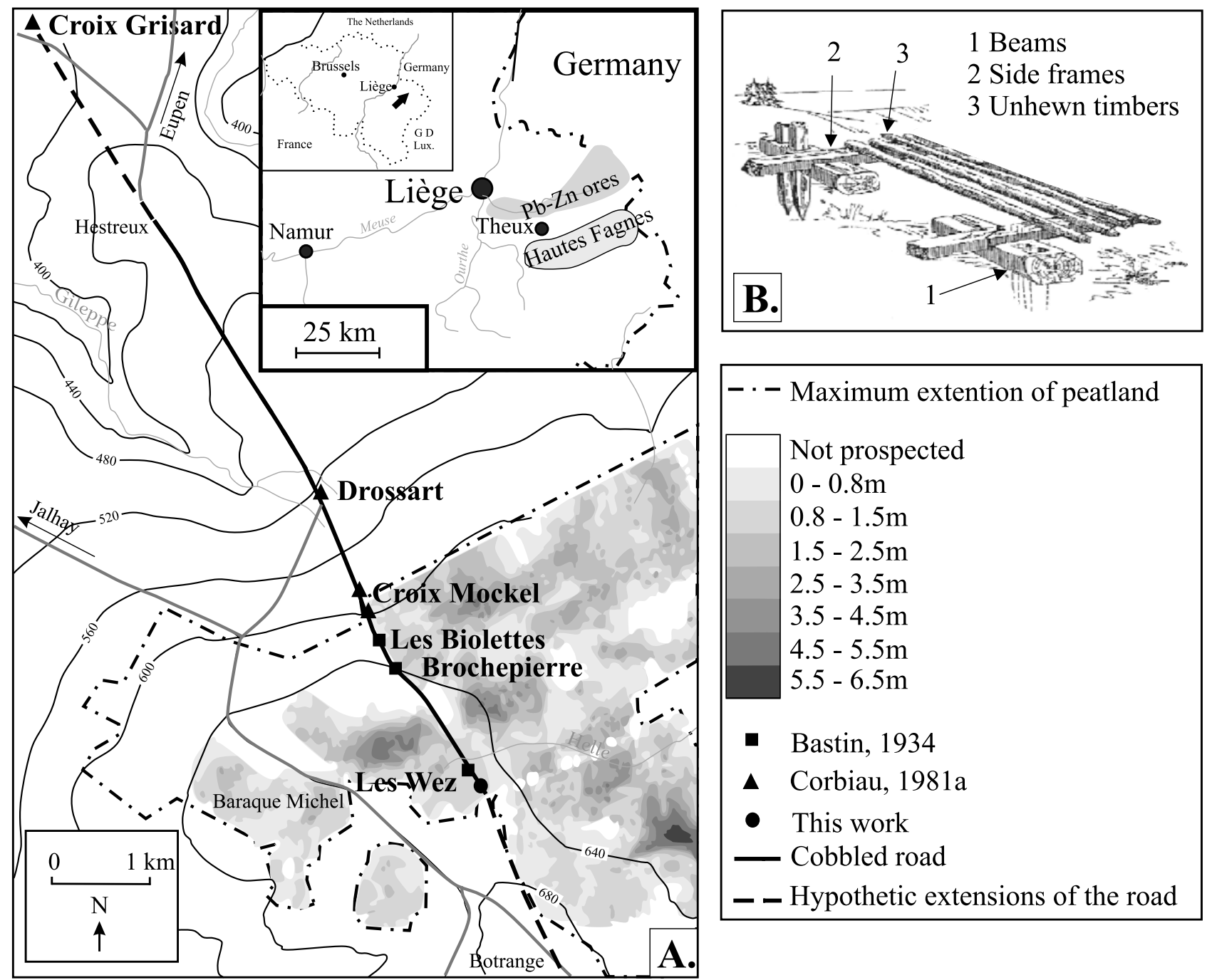

- - - Maximum extention of peatland

Not prospected

$0-0.8 \mathrm{~m}$

$0.8-1.5 \mathrm{~m}$

$1.5-2.5 \mathrm{~m}$

$2.5-3.5 \mathrm{~m}$

$3.5-4.5 \mathrm{~m}$

$4.5-5.5 \mathrm{~m}$

$5.5-6.5 \mathrm{~m}$

- Bastin, 1934

A Corbiau, 1981a

- This work

— Cobbled road

- - Hypothetic extensions of the road

Fig. 1. (A) Location map of the Hautes Fagnes plateau, the Pb-Zn ores of E-Belgium (Cauet et al., 1982; Dejonghe, 1998), the cobbled road and the various excavations (after Corbiau, 1981a). Peat thickness reported from Wastiaux and Schumacker (2003). (B) Sketch of the findings from Bastin (1934) redrawn by Mertens (1957).

sediments (Corbiau, 1981a) as this kind of wood basement is not necessary to support the road when the substratum is not waterlogged. From base to top, this bearing beechwooden structure was composed of three parts: (1) a set of beams perpendicular to the road, (2) girder/side frame parallel to the road and fitted into the beams, (3) an assembly of unhewn timbers lying perpendicular to the road. The cobbling overlying the wooden foundations is composed of quartzite blocks from the Revin group (Cambrian), a rock common as erratic blocks on the Hautes Fagnes plateau. Finer sediments of variable grain-size ranging from clay to fine gravel are scattered between the cobbles. Given these particular structural and compositional characteristics, although without any age-dating control, Bastin (1934) attributed a Roman origin to the road. Much later, Corbiau (1981a) carried out three new excavations in the northern part of the road where it was built across a very thin peat layer or on non-peaty sediment (Fig. 1A). The alder-wooden structure at these excavations was either missing or consisted of a single unhewn timbers assembly under the cobblestones. Wood fragments were radiocarbon dated to a period between the 5 th and the 8 th centuries AD (Damb- lon, 1994). Therefore, Corbiau (1981a) advocated a Merovingian age for this part of the road. This younger age was not contradictory with the estimation of Bastin (1934), as Corbiau (1981a) mentioned that these new excavations could be non-contemporaneous from those previously studied. Three wood fragments kept from the excavations of Bastin (1934) were later radiocarbon dated and also provided contradictory age-dating of BC 170, BC 248 (Lewalle, 1963) and AD $550 \pm 50$ (Corbiau, 1981a) that were never discussed. Subsequently, Dalemans and Streel (1986) did a palynological investigation of four cores from the southernmost site studied by Bastin (Fig. 1A) in an attempt to constrain the age-dating of the road construction. They assigned the first impact of the road to small eroded quartzite fragments found in the peat. Using this proxy for the lowest level of the road, these authors compared the pollen record with that of Persch (1950) and estimated the building of the road to have occurred around AD 700 (Dalemans and Streel, 1986).

The possible destination of the road was also thoroughly discussed. In the middle of the 19th century the cobbled road was considered to be part of a Roman road 
linking the cities of Maastricht and Trier (Corbiau, 1981b). Later on, it was associated to a Roman road called Via Mansuerisca, which has been cited in historical texts since 670 AD (Corbiau, 1981b). Several tracks were proposed to link the cobbled road to Trier or to the Köln-Trier Roman road. However, as stated by Corbiau (1981b) these tracks are still hypothetical. Systematic archaeological investigations are needed as despite these numerous studies, the age of the road and its purpose and destination, which may be crucial factors in determining its age, are still under debate.

Moreover, of wider interest, it is well known that the Romans built the first extensive road web across Europe. First built for military purposes, these roads were further developed for trade purposes (Chevallier, 1972). In Belgium, the Roman road system was extended ca. 20 BC, mainly for the defence of northern borders against possible Barbarian invasions, but also for political purposes and for trade between the different cities (Corbiau, 2006). At the Roman Empire apogee, roads covered $150,000 \mathrm{~km}$ (Chevallier, 1972) throughout Europe. The environmental impacts provoked by such an intense and modern road web has however never been investigated.

Roman road engineers generally avoided any wetlands, river overbank and inundation plains (Chevallier, 1972). For these reasons, to the authors' knowledge, apart from one other site in Austria (via Claudia Augusta near Lermoos city), the archaeological site described here is unique for the Roman Empire. Indeed, due to its construction in a peatland, the road is very well preserved. Moreover, it offers a unique opportunity to study possible pollution that could be recorded in the surrounding peat accumulation.

In order to answer the various historical, geographical and environmental questions mentioned above, the geochemical and $\mathrm{Pb}$ isotopic records in two peat columns taken alongside the cobbled road have been studied. These analyses are accompanied by radiocarbon dates. Local problems discussed in the present study are (1) documenting the purpose of such a road by placing it in a geographical and historical context, (2) providing new clues to better constrain the age of its construction and (3) providing an age of possible early $\mathrm{Pb}-\mathrm{Zn}$ mining in Belgium. On a broader scale, this study also (1) assesses the environmental impact of such early roads and (2) discusses $\mathrm{Pb}$ and $\mathrm{Zn}$ mobility in peat.

\section{Using geochemistry in geoarchaeology}

Elemental geochemistry and $\mathrm{Pb}$ isotope analyses have been successfully used for investigations of peat sequences to reconstruct pollution chronologies in Europe (e.g. Brännvall et al., 1999; Martínez-Cortizas et al., 2002; Novak et al., 2003; Shotyk et al., 2003; Le Roux et al., 2004a). Contaminant metals, particularly $\mathrm{Pb}$ and $\mathrm{Zn}$, linked to mining and smelting activities, have been monitored at various European sites including West Germany, (e.g. Kempter and Frenzel, 1999), Switzerland, (e.g. Shotyk et al., 2003), France, (e.g. Baron et al., 2005) and East-Belgium, (e.g. Sonke et al., 2002). In some cases, early pollution could be evidenced, especially if the polluting source was in the vicinity of the study site, (e.g. West et al., 1997; Mighall et al., 2002; Baron et al., 2005). Previous research dealing with pollution histories in Belgium have been carried out in ombrotrophic bogs from the Hautes Fagnes plateau, SE-Belgium (Kempter, 1996; Gérard, 2004; Goormaghtigh, 2005; De Vleeschouwer et al., 2007) and peaty sediments (Sonke et al., 2002). These studies showed that anthropogenic impact dated back to early Roman times.

In the specific field of geoarchaeology, little attention has been given to the potential of tracing past pollution using geochemistry (Mighall et al., 2006; Nriagu, 1996). However, previous studies have successfully demonstrated the potential of this approach, (e.g. Elmaleh et al., 2007; Grattan et al., 2007; Baron et al., 2005; Le Roux et al., 2004b). To the authors' knowledge, this study constitutes the first investigation of environmental impact due to road use during the Roman Empire. It provides a good example of how geochemistry can be used as a tool to broaden knowledge in the role that early civilisations played on the environment.

\section{Materials and methods}

\subsection{Coring and subsampling}

In July 2004, an archaeological excavation was carried out by the "Direction de l'Archéologie du Ministère de la Région Wallonne" (Corbiau, 2005) a few tens of metres from the original site studied by Bastin (1934). Fig. 2A shows a cross-section of the excavation. The $30-\mathrm{cm}$ thick peat covering the road was removed and a $1.2-\mathrm{m}$ deep trench was dug in the southern section of the road, perpendicularly to its direction. The revealed road structure (Fig. 2A) was similar to the section previously studied by Bastin (1934). The peatland is developed on a slight slope. It is now partly fed by small eastward surface streams.

Two peat columns (CR1, downhill and CR2, uphill; Fig. 2B) were collected in the trench on each side of the road using plastic U-boxes $(20 \mathrm{~cm} \times 10 \mathrm{~cm} \times 6 \mathrm{~cm})$. CR1 and CR2 measure approximately $103 \mathrm{~cm}$ and $125 \mathrm{~cm}$ long, respectively. An undisturbed $2 \mathrm{~cm}$-thick slice was cut along the side of each block and impregnated with resin. The peat blocks were then cut into $1-\mathrm{cm}$ thick slices with plastic tools. Note that $0 \mathrm{~cm}$ is at the bottom of the cores.

As there is surface runoff, any possible environmental impact of the road should be more accurately recorded down slope. Therefore, most of the results were obtained on CR1.

\subsection{Thin sections}

Thin sections were made using the method described in De Vleeschouwer et al. (2008). The peat slices were freezedried under high vacuum (6-8 mbar) and impregnated with resin under low vacuum (700-1000 mbar). Polymerisation was achieved in a drying-oven $\left(40^{\circ} \mathrm{C}, 72 \mathrm{~h}\right)$ and then under laboratory conditions $(100 \mathrm{~h})$. Blocks were then polished and thin sections were prepared. 
A

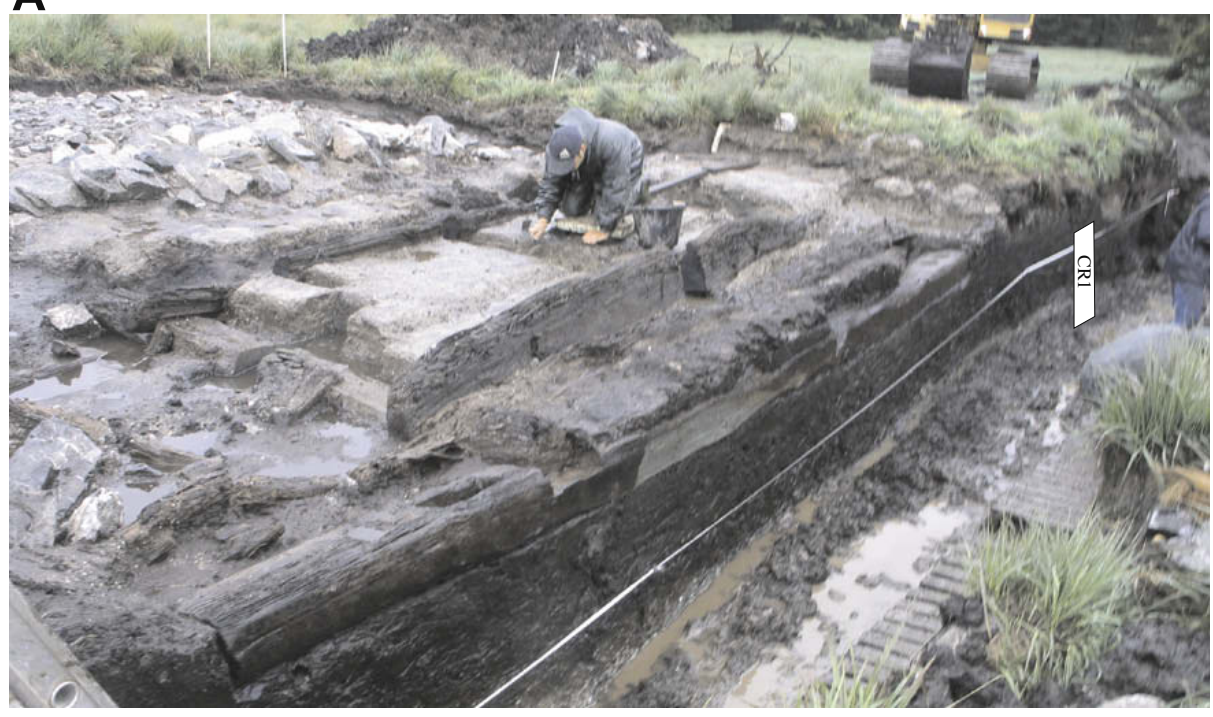

B
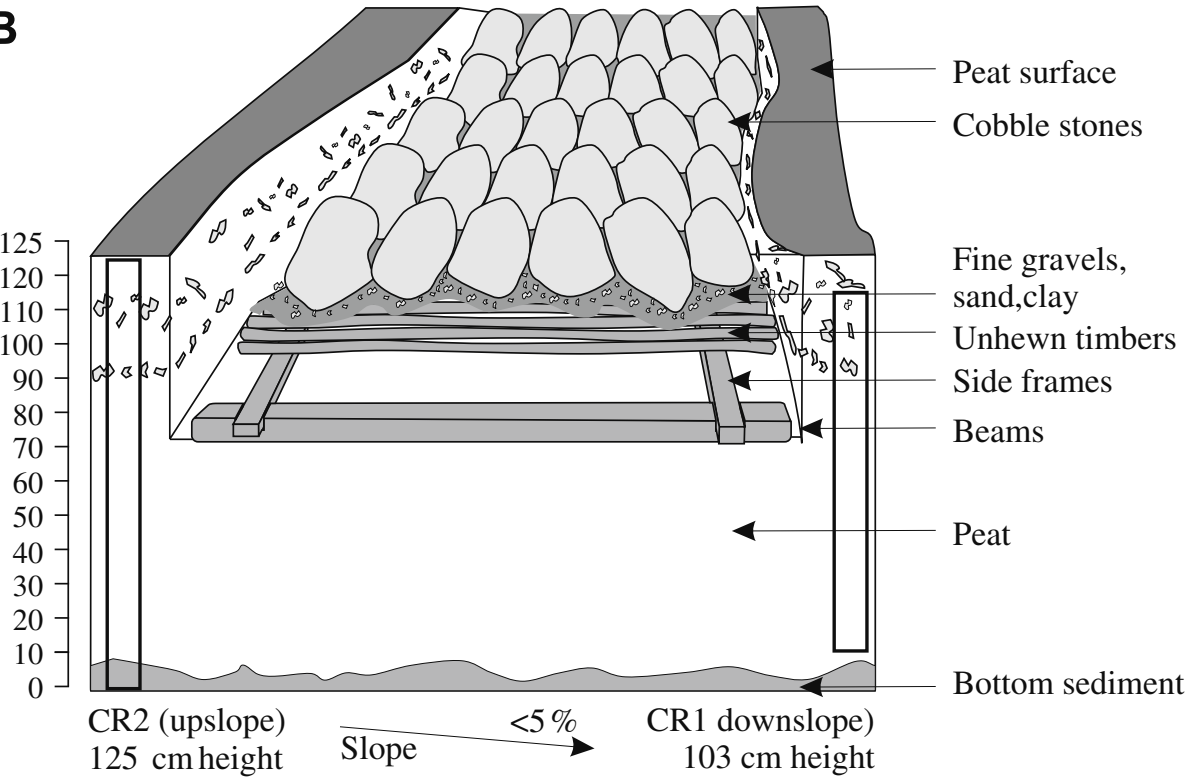

Fig. 2. (A) Picture of the excavation in course of study. The position of CR1 is shown. (B) Schematic drawing of the two peat sections (CR1 and CR2) taken aside the road. Wooden structure after Corbiau (2005). Vertical scale is exaggerated five times. CR1 is $103 \mathrm{~cm}$ long and is located downhill from the road section and CR2 is $125 \mathrm{~cm}$ long and is located uphill from the road section.

\subsection{Geochemistry}

One-cm thick slices of peat were freeze-dried and milled in an agate jar pulverisette ( $400 \mathrm{rpm}, 1 \mathrm{~h}$ ). Pellets were prepared by pressing $3 \mathrm{~g}$ of peat powder $(200 \mathrm{kN} /$ $\mathrm{cm}^{2}$ ). The following elements were analysed using X-ray fluorescence (ARL 9400 XP, URPGE, ULg): Si, Al, Ca, Na, K, $\mathrm{Zn}$ and $\mathrm{Pb}$. Thirty-nine and 46 samples were analyzed in CR1 and CR2, respectively. International reference material such as coals (CLB-1, NIST 1632b), lichen (BCR-482), pond sediments (NIES-2), tea leaves (NIES-7), exhaust particles (NIES-8) and marine sediments (JSD-2, JSD-3, SGR 44) were used as working standards for trace elements. In-house standards, made by mixing together a low ash peat with Merck quality oxides or carbonates for each of the major element, were used for the calibration of major elements. The resulting mix was then progressively diluted to obtain five aliquots of different concentrations. Their respective concentrations were previously measured by inductively coupled plasma atomic emission spectrometry (ICP-AES) at the "Musée Royal d'Afrique Centrale" (MRAC) in Tervuren (Belgium) together with the low ash peat after ashing and acid digestion in a clean laboratory (De Vleeschouwer, 2007). Repeated measurements $(n=20)$ allowed the estimation of reproducibility and accuracy (Table 1 ).

\subsection{Lead isotopes}

Twelve samples from CR 1 and five samples from CR 2 (see Table 2 for depths) were prepared in a laminar flow clean air cabinet using the following protocol: $100 \mathrm{mg}$ of peat powder were digested in $30 \mathrm{~mL}$ open Savillex ${ }^{\circledR}$ beakers $\left(95^{\circ} \mathrm{C}, 72 \mathrm{~h}\right.$ ) using successive additions of $\mathrm{H}_{2} \mathrm{O}_{2}$ $30 \%$ p.a. and $\mathrm{HNO}_{3} 14 \mathrm{~N}$ cc sub in a proportion of $2: 1$. 
Table 1

Selected elemental geochemistry in CR1 and CR2 cores

\begin{tabular}{|c|c|c|c|c|c|c|c|c|c|c|c|c|c|}
\hline & \multicolumn{6}{|l|}{ CR1 } & & \multicolumn{6}{|l|}{ CR2 } \\
\hline & $\mathrm{Si}$ & $\mathrm{Al}$ & $\mathrm{Na}$ & $\mathrm{K}$ & $\mathrm{Zn}$ & $\mathrm{Pb}$ & & $\mathrm{Si}$ & $\mathrm{Al}$ & $\mathrm{Na}$ & K & $\mathrm{Zn}$ & $\mathrm{Pb}$ \\
\hline Reprod. (\%) & 99 & 99 & 97 & 84 & 96 & 87 & Reprod. (\%) & 99 & 99 & 97 & 84 & 96 & 87 \\
\hline Acc (\%) & 3 & 6 & 29 & 21 & 20 & 6 & Acc $(\%)$ & 3 & 6 & 29 & 21 & 20 & 6 \\
\hline LD & 8.1 & 1.7 & 2.4 & 0.1 & 1.0 & 4.9 & LD & 8.1 & 1.7 & 2.4 & 0.1 & 1.0 & 4.9 \\
\hline LSQ & 16.3 & 3.3 & 5 & 0.21 & 1.9 & 9.8 & LSQ & 16.3 & 3.3 & 5 & 0.21 & 1.9 & 9.8 \\
\hline LQ & 27.1 & 5.6 & 8 & 0.35 & 3.2 & 16.4 & LQ & 27.1 & 5.6 & 8 & 0.35 & 3.2 & 16.4 \\
\hline Height $(\mathrm{cm})$ & & & & & & & Height $(\mathrm{cm})$ & & & & & & \\
\hline 102 & 28.4 & 9.9 & 1.1 & 1.3 & 223 & 329 & 124.5 & 8.8 & 4.0 & 0.4 & 0.6 & 640 & 455 \\
\hline 100.5 & 17.6 & 9.1 & 0.8 & 1.3 & 280 & 299 & 123.5 & 8.4 & 4.0 & 0.4 & 0.6 & 940 & 578 \\
\hline 99.5 & 33.0 & 10.2 & 1.1 & 1.2 & 299 & 134 & 122.5 & 10.8 & 4.7 & $\underline{0.5}$ & 0.7 & 786 & 479 \\
\hline 98.5 & 25.4 & 9.6 & 1.0 & 1.2 & 414 & 77 & 121.5 & 12.9 & 5.3 & $\underline{0.5}$ & 0.8 & 427 & 312 \\
\hline 97.5 & 25.2 & 9.1 & 0.9 & 1.1 & 466 & 63 & 119.5 & 12.7 & 4.9 & 0.5 & 0.7 & 203 & 132 \\
\hline 96.5 & 24.7 & 8.2 & 0.8 & 1.0 & 333 & 43 & 118.5 & 10.7 & 4.4 & 0.4 & 0.6 & 199 & 104 \\
\hline 95.5 & 19.3 & 7.2 & $\underline{0.7}$ & 0.9 & 397 & 37 & 117.5 & 7.7 & 4.0 & 0.4 & 0.46 & 174 & 86 \\
\hline 94.5 & 11.6 & 5.0 & $\underline{0.5}$ & 0.7 & 588 & 41 & 116.5 & 5.9 & 3.5 & 0.33 & 0.35 & 162 & 66 \\
\hline 93.5 & $\underline{1.82}$ & 3.1 & 0.26 & 0.17 & 792 & 42 & 114.5 & 5.2 & 3.3 & 0.29 & 0.31 & 132 & 58 \\
\hline 92.5 & 1.55 & 2.8 & 0.24 & 0.14 & 672 & 36 & 113.5 & 6.5 & 3.4 & 0.32 & 0.38 & 104 & 50 \\
\hline 91.5 & 1.36 & 2.7 & 0.24 & 0.11 & 689 & 31 & 112.5 & 5.8 & 3.3 & 0.30 & 0.36 & 87 & 46 \\
\hline 90.5 & 1.24 & 2.6 & 0.24 & 0.11 & 626 & 28 & 111.5 & 11.4 & 3.9 & 0.29 & 0.5 & 46 & 26 \\
\hline 89.5 & $\underline{1.98}$ & 2.8 & 0.25 & 0.18 & 540 & 29 & 109.5 & $\underline{2.0}$ & 2.2 & $<\mathrm{LD}$ & 0.11 & 76 & 31 \\
\hline 88.5 & 5.7 & 3.5 & 0.34 & 0.42 & 522 & 29 & 108.5 & 1.6 & 2.0 & $<\mathrm{LD}$ & 0.08 & 73 & 29 \\
\hline 87.5 & 20.9 & 7.6 & 0.8 & 1.1 & 233 & $\underline{14.4}$ & 107.5 & $\underline{2.0}$ & 2.1 & $<\mathrm{LD}$ & 0.13 & 68 & 28 \\
\hline 86.5 & 13.6 & 5.4 & $\underline{0.6}$ & 0.8 & 390 & 20 & 106.5 & 5.2 & 3.0 & 0.4 & 0.44 & 52 & 21 \\
\hline 85.5 & 6.7 & 4.0 & 0.4 & 0.5 & 517 & 33 & 104.5 & 1.5 & 1.67 & $<\mathrm{LD}$ & 0.08 & 45 & 15.8 \\
\hline 84.5 & 9.0 & 4.1 & 0.4 & 0.6 & 420 & 28 & 103.5 & 1.1 & 1.44 & $<\mathrm{LD}$ & 0.042 & 39 & 16.6 \\
\hline 83.5 & 18.2 & 5.4 & $\underline{0.7}$ & 0.9 & 339 & 23 & 102.5 & 1.1 & 1.40 & $<\mathrm{LD}$ & 0.043 & 53 & 14.5 \\
\hline 82.5 & 28.4 & 7.5 & 0.9 & 1.0 & 164 & $\underline{14.6}$ & 101.5 & 1.2 & 1.38 & 0.34 & 0.06 & 27 & 12.9 \\
\hline 81.5 & 33.2 & 6.7 & $\underline{0.7}$ & 0.8 & 114 & 10.9 & 99.5 & 1.2 & 1.29 & $<\mathrm{LD}$ & 0.05 & 9 & 8.1 \\
\hline 80.5 & $\underline{2.28}$ & 2.4 & 0.25 & 0.15 & 712 & 40 & 98.5 & 1.3 & 1.27 & $<\mathrm{LD}$ & 0.05 & 9 & 8.1 \\
\hline 79.5 & 1.52 & 2.3 & 0.26 & 0.09 & 931 & 66 & 97.5 & 1.5 & 1.43 & $<\mathrm{LD}$ & 0.05 & 20 & 4.9 \\
\hline 78.5 & 1.11 & 2.1 & 0.24 & 0.06 & 778 & 55 & 96.5 & 1.1 & 1.33 & $<\mathrm{LD}$ & 0.035 & 8 & $\underline{11.8}$ \\
\hline 77.5 & 0.88 & 1.7 & 0.24 & $\underline{0.031}$ & 1037 & 65 & 95.5 & 1.2 & 1.38 & $<\mathrm{LD}$ & 0.039 & 9 & $\underline{10.5}$ \\
\hline 76.5 & 1.13 & 1.9 & 0.24 & 0.06 & 1034 & 77 & 94.5 & 1.2 & 1.37 & $<\mathrm{LD}$ & 0.040 & $<\mathrm{LD}$ & 6.8 \\
\hline 75.5 & 1.13 & 1.8 & $<\mathrm{LD}$ & 0.06 & 457 & 46 & 93.5 & 1.1 & 1.32 & $<\mathrm{LD}$ & $\underline{0.023}$ & $<\mathrm{LD}$ & $\underline{11.8}$ \\
\hline 74.5 & 1.45 & 1.9 & $<\mathrm{LD}$ & 0.09 & 251 & 48 & 92.5 & 1.1 & 1.35 & $<\mathrm{LD}$ & $\underline{0.024}$ & $<\mathrm{LD}$ & 11.2 \\
\hline 73.5 & $\underline{1.92}$ & 1.9 & $<\mathrm{LD}$ & 0.13 & 158 & 40 & 91.5 & 1.1 & 1.34 & $<\mathrm{LD}$ & $\underline{0.021}$ & $<\mathrm{LD}$ & 8.9 \\
\hline 72.5 & $\underline{2.27}$ & 1.9 & $<\mathrm{LD}$ & 0.17 & 109 & 39 & 90.5 & 1.0 & 1.29 & $<\mathrm{LD}$ & 0.013 & $<\mathrm{LD}$ & 14.0 \\
\hline 71.5 & 1.94 & 1.8 & $<\mathrm{LD}$ & 0.14 & 84 & 43 & 89.5 & $<\mathrm{LD}$ & 1.24 & $<\mathrm{LD}$ & $<\mathrm{LD}$ & $<\mathrm{LD}$ & 11.4 \\
\hline 70.5 & $\underline{1.66}$ & 1.65 & $<\mathrm{LD}$ & 0.11 & 49 & 41 & 88.5 & 0.9 & 1.28 & $<\mathrm{LD}$ & $<\mathrm{LD}$ & $<\mathrm{LD}$ & 7.9 \\
\hline 60.5 & $\overline{0.95}$ & 1.34 & $<\mathrm{LD}$ & 0.045 & $<\mathrm{LD}$ & $\underline{10.7}$ & 87.5 & $<\mathrm{LD}$ & 1.24 & $<\mathrm{LD}$ & $<\mathrm{LD}$ & $<\mathrm{LD}$ & 10.9 \\
\hline 50.5 & 1.43 & 1.46 & $<\mathrm{LD}$ & 0.10 & $<\mathrm{LD}$ & 6.0 & 86.5 & $<\mathrm{LD}$ & 1.18 & $<\mathrm{LD}$ & $<\mathrm{LD}$ & $<\mathrm{LD}$ & 14.5 \\
\hline 40.5 & $<\mathrm{LD}$ & 1.23 & $<\mathrm{LD}$ & $<\mathrm{LD}$ & $<\mathrm{LD}$ & 13.7 & 85.5 & $<\mathrm{LD}$ & 1.12 & $<\mathrm{LD}$ & $<\mathrm{LD}$ & $<\mathrm{LD}$ & 7.3 \\
\hline 30.5 & 1.06 & 1.64 & $<\mathrm{LD}$ & 0.037 & $<\mathrm{LD}$ & 6.2 & 84.5 & $<\mathrm{LD}$ & 1.19 & $<\mathrm{LD}$ & $<\mathrm{LD}$ & $<\mathrm{LD}$ & 9.1 \\
\hline 20.5 & $\underline{1.88}$ & 2.4 & $<\mathrm{LD}$ & 0.18 & $<\mathrm{LD}$ & 7.3 & 83.5 & $<\mathrm{LD}$ & 1.32 & $<\mathrm{LD}$ & 0.019 & $<\mathrm{LD}$ & 17 \\
\hline 9.5 & 4.2 & 3.6 & 0.28 & 0.38 & $<\mathrm{LD}$ & 7.2 & 80.5 & $<\mathrm{LD}$ & 1.24 & $<\mathrm{LD}$ & $<\mathrm{LD}$ & $<\mathrm{LD}$ & 15.2 \\
\hline \multirow[t]{8}{*}{0.5} & 14.8 & 8.9 & 0.8 & 1.2 & $<\mathrm{LD}$ & 6.0 & 70.5 & $<\mathrm{LD}$ & 1.23 & $<\mathrm{LD}$ & 0.011 & $<\mathrm{LD}$ & 13.2 \\
\hline & & & & & & & 60.5 & $<\mathrm{LD}$ & 1.39 & $<\mathrm{LD}$ & $<\mathrm{LD}$ & $<\mathrm{LD}$ & 19 \\
\hline & & & & & & & 50.5 & 0.9 & 2.0 & $<\mathrm{LD}$ & 0.014 & $<\mathrm{LD}$ & 27 \\
\hline & & & & & & & 40.5 & 2.9 & 2.7 & $<\mathrm{LD}$ & 0.28 & $<\mathrm{LD}$ & 25 \\
\hline & & & & & & & 30.5 & $\underline{2.1}$ & 2.6 & $<\mathrm{LD}$ & 0.19 & $<\mathrm{LD}$ & 10.2 \\
\hline & & & & & & & 20.5 & 4.6 & 4.3 & 0.32 & 0.5 & $<\mathrm{LD}$ & 10.3 \\
\hline & & & & & & & 10.5 & 31.8 & 24 & 2.1 & 2.3 & $<\mathrm{LD}$ & 16.6 \\
\hline & & & & & & & 0.5 & 34 & 25 & 2.3 & 2.3 & 5 & 18 \\
\hline
\end{tabular}

Results are given in $\mathrm{mg} / \mathrm{g}$ for major elements and in $\mu \mathrm{g} / \mathrm{g}$ for trace elements in dry peat, respectively. Values in italics, underlined and in bold are respectively qualitative $(3 \sigma-6 \sigma)$, semi-quantitative $(6 \sigma-9 \sigma)$ and quantitative $(>9 \sigma)$. LD, LSQ and LQ mean respectively limit of detection, limit of semiquantification and limit of quantification.

Samples were then dried, $\mathrm{HF} 24 \mathrm{~N}$ suprapur and $\mathrm{HNO}_{3} 14 \mathrm{~N}$ cc sub were added in a proportion of 10:1 and the beakers were closed and heated $\left(130^{\circ} \mathrm{C}, 72 \mathrm{~h}\right)$. After drying, $2 \mathrm{~mL}$ of $\mathrm{HCl} 6.8 \mathrm{~N}$ were added and the solutions were slowly evaporated at $75^{\circ} \mathrm{C}$. The dried residues were finally dissolved in $0.5 \mathrm{~mL} \mathrm{HBr} 0.8 \mathrm{~N}$. The $\mathrm{Pb}$ separation was achieved by successive $\mathrm{HBr}$ and $\mathrm{HCl}$ additions on pre-conditioned columns filled with an anionic resin (AG1X8). The eluted pure $\mathrm{Pb}$ solution was evaporated and stored. Before isotopic analysis, the Pb elution was re-dissolved in $100 \mu \mathrm{L}$ of $\mathrm{HNO}_{3} 14 \mathrm{~N}$ cc sub, evaporated and finally dissolved in $1.5 \mathrm{~mL}$ of $\mathrm{HNO}_{3}$ $0.05 \mathrm{~N}$.

Lead isotopes were measured using a Nu-plasma multi collector-inductively coupled plasma-mass spectrometer (MC-ICP-MS) at the 'Département des Sciences de la Terre et de l'Environnement' (DSTE - Université Libre de Bruxelles). 
Table 2

$\mathrm{Pb}$-isotopic ratios in selected samples from CR1 and CR2

\begin{tabular}{|c|c|c|c|c|c|c|c|c|c|c|}
\hline Height $(\mathrm{cm})$ & ${ }^{208} \mathrm{~Pb} /{ }^{204} \mathrm{~Pb}$ & $2 s d$ & ${ }^{207} \mathrm{~Pb} /{ }^{204} \mathrm{~Pb}$ & $2 s d$ & ${ }^{206} \mathrm{~Pb} /{ }^{204} \mathrm{~Pb}$ & $2 s d$ & ${ }^{208} \mathrm{~Pb} /{ }^{206} \mathrm{~Pb}$ & $2 s d$ & ${ }^{207} \mathrm{~Pb} /{ }^{206} \mathrm{~Pb}$ & $2 s d$ \\
\hline \multicolumn{11}{|l|}{ CR1 } \\
\hline $100.5^{*}$ & 38.1746 & 0.0169 & 15.6117 & 0.0067 & 18.1879 & 0.0079 & 2.09887 & 0.00037 & 0.85830 & 0.00012 \\
\hline 100.5 & 38.1807 & 0.0154 & 15.6139 & 0.0057 & 18.1916 & 0.0064 & 2.09874 & 0.00045 & 0.85825 & 0.00013 \\
\hline 98.5 & 38.3991 & 0.0177 & 15.6288 & 0.0068 & 18.4255 & 0.0067 & 2.08402 & 0.00036 & 0.84815 & 0.00011 \\
\hline 93.5 & 38.3355 & 0.0178 & 15.6260 & 0.0062 & 18.3709 & 0.0067 & 2.08673 & 0.00037 & 0.85053 & 0.00010 \\
\hline 85.5 & 38.3457 & 0.0152 & 15.6279 & 0.0061 & 18.3682 & 0.0066 & 2.08764 & 0.00044 & 0.85076 & 0.00012 \\
\hline 81.5 & 38.6681 & 0.0208 & 15.6603 & 0.0079 & 18.7404 & 0.0081 & 2.06340 & 0.00004 & 0.83561 & 0.00012 \\
\hline 80.5 & 38.3528 & 0.0160 & 15.6248 & 0.0058 & 18.3868 & 0.0060 & 2.08591 & 0.00038 & 0.84974 & 0.00011 \\
\hline 77.5 & 38.3120 & 0.0106 & 15.6236 & 0.0041 & 18.3299 & 0.0053 & 2.09010 & 0.00029 & 0.85230 & 0.00008 \\
\hline 75.5 & 38.3506 & 0.0169 & 15.6252 & 0.0061 & 18.3657 & 0.0074 & 2.08813 & 0.00045 & 0.85073 & 0.00011 \\
\hline 70.5 & 38.3883 & 0.0149 & 15.6268 & 0.0057 & 18.3984 & 0.0072 & 2.08641 & 0.00035 & 0.84928 & 0.00011 \\
\hline 60.5 & 38.4817 & 0.0180 & 15.6387 & 0.0067 & 18.4532 & 0.0072 & 2.08542 & 0.00034 & 0.84744 & 0.00011 \\
\hline 40.5 & 38.7448 & 0.0290 & 15.6745 & 0.0079 & 18.8368 & 0.0181 & 2.05707 & 0.00072 & 0.83216 & 0.00017 \\
\hline 9.5 & 38.9589 & 0.0153 & 15.7012 & 0.0057 & 19.1661 & 0.0071 & 2.03270 & 0.00038 & 0.81917 & 0.00011 \\
\hline \multicolumn{11}{|l|}{ CR2 } \\
\hline $123.5_{* *}$ & 38.0000 & 0.0098 & 15.5952 & 0.0039 & 18.0354 & 0.0053 & 2.10686 & 0.00020 & 0.86468 & 0.00006 \\
\hline $109.5^{* *}$ & 38.3886 & 0.0105 & 15.6212 & 0.0038 & 18.4096 & 0.0035 & 2.08510 & 0.00022 & 0.84852 & 0.00005 \\
\hline 109.5 & 38.3879 & 0.0126 & 15.6212 & 0.0053 & 18.4111 & 0.0049 & 2.08495 & 0.00020 & 0.84848 & 0.00007 \\
\hline 102.5 & 38.4798 & 0.0084 & 15.6297 & 0.0032 & 18.4918 & 0.0053 & 2.08085 & 0.00023 & 0.84521 & 0.00008 \\
\hline 96.5 & 38.6165 & 0.0124 & 15.6488 & 0.0042 & 18.6344 & 0.0049 & 2.07228 & 0.00021 & 0.83979 & 0.00007 \\
\hline 50.5 & 38.8087 & 0.0113 & 15.6872 & 0.0036 & 19.0550 & 0.0043 & 2.03662 & 0.00027 & 0.82325 & 0.00007 \\
\hline
\end{tabular}

"sd" refers to standard deviation. Duplicate is denoted by " while replicate is denoted by ${ }^{* *}$.

As an internal isotopic standard, a Tl solution was added to each sample and standard to monitor and correct for mass dependent isotopic fractionation. Whilst the samples were characterized by a large variability in $\mathrm{Pb}$ concentrations, the sample solutions were prepared to obtain a beam intensity in the Axial collector $\left({ }^{204} \mathrm{~Pb}\right)$ of a minimum of $100 \mathrm{mV}$ and $\mathrm{a} \mathrm{Pb} / \mathrm{Tl}$ ratio of $\sim 5$, matching the $\mathrm{Pb}$ and $\mathrm{Tl}$ concentrations of the NBS981 standard (200 ppb in Pb, with $50 \mathrm{ppb}$ in $\mathrm{Tl}$ ). The NBS981 standard was measured several times before each analytical session and between each two samples. Forty-one analyses of the standard were performed and gave the following mean values: ${ }^{208} \mathrm{~Pb} /{ }^{204} \mathrm{~Pb}=36.7131 \pm$ $0.0071(2 \mathrm{SD}),{ }^{207} \mathrm{~Pb} /{ }^{204} \mathrm{~Pb}=15.4959 \pm 0.0027(2 \mathrm{SD}),{ }^{206} \mathrm{~Pb} /{ }^{204} \mathrm{~Pb}=$ $16.9392 \pm 0.0028$ (2SD), which are in good agreement with long term laboratory values $\left(n=1000,{ }^{208} \mathrm{~Pb} /{ }^{204} \mathrm{~Pb}=\right.$ $36.7130 \pm 0.012 \quad(2 \mathrm{SD}), \quad{ }^{207} \mathrm{~Pb} /{ }^{204} \mathrm{~Pb}=15.4950 \pm 0.004$ (2SD), ${ }^{206} \mathrm{~Pb} /{ }^{204} \mathrm{~Pb}=16.9393 \pm 0.0044(2 \mathrm{SD})$, and the MCICP-MS values of Weis et al. (2006). These values are also in agreement with TIMS triple-spike values previously published by Galer and Abouchami (1998). Although the NBS981 standard results were within the error of the triple-spike values after online correction for instrumental mass bias by Tl addition, the sample results were further corrected by the sample-standard bracketing method (as described by White et al., 2000 and Weis et al., 2006) to circumvent any instrumental drift during the analytical session. A duplicate (i.e. second sample treated the same way) of CR1 (100-101 cm) and a replicate (i.e. second analysis of the same sample) of CR2 $(109-110 \mathrm{~cm})$ were also measured to check the reproducibility (Table 2 ).

\subsection{Radiocarbon dating}

Six samples of bulk peat powder from CR1 were ${ }^{14} \mathrm{C}$-dated. Samples were either $1 \mathrm{~cm}$ thick $(10-11 \mathrm{~cm}, 80-81 \mathrm{~cm}$ and $82-83 \mathrm{~cm})$, or $2 \mathrm{~cm}$ thick, i.e. a mix of two $1 \mathrm{~cm}$-thick samples (74-76 cm, 76-78 cm and 78-80 cm). "Poz" sam- ples were measured by acceleration mass spectrometry (1.5 SDH-Pelletron Model "Compact Carbon A.M.S.") at Poznan Radiocarbon Laboratory (Poland) after pre-treatment using an acid-alkali-acid washing sequence in order to remove humic/fulvic acids and bacterial $\mathrm{CO}_{2}$ (Speranza et al., 2000). "GrN" samples were measured by conventional counting at Center for Isotope Research in Groningen (The Netherlands).

\section{Results}

\subsection{Selected major elements ( $\mathrm{Si}, \mathrm{Al}, \mathrm{Na}, \mathrm{K}$ )}

In both $\mathrm{CR} 1$ and $\mathrm{CR} 2$, concentrations of $\mathrm{Si}, \mathrm{Al}$ and $\mathrm{K}$ display similar patterns (Table 1). In CR1, concentrations decrease from the base of the section ( $\mathrm{Si}=148 \mathrm{mg} / \mathrm{g}$, $\mathrm{Al}=89 \mathrm{mg} / \mathrm{g}, \quad \mathrm{Na}=8 \mathrm{mg} / \mathrm{g}$ and $\mathrm{K}=12 \mathrm{mg} / \mathrm{g}$ ) to $30 \mathrm{~cm}$ $(\mathrm{Si}=10.6 \mathrm{mg} / \mathrm{g}, \mathrm{Al}=16.4 \mathrm{mg} / \mathrm{g}, \mathrm{Na}<\mathrm{DL}$ and $\mathrm{K}=0.37 \mathrm{mg} /$ g) and are low between 30 and $80 \mathrm{~cm}$. Between 80 and $103 \mathrm{~cm}$, concentrations fluctuate from low ( $\mathrm{Si}=12.4 \mathrm{mg}$ / g, $\mathrm{Al}=24 \mathrm{mg} / \mathrm{g}, \mathrm{Na}=2.4 \mathrm{mg} / \mathrm{g}$ and $\mathrm{K}=1.1 \mathrm{mg} / \mathrm{g}$ ) to high values $(\mathrm{Si}=332 \mathrm{mg} / \mathrm{g}, \mathrm{Al}=102 \mathrm{mg} / \mathrm{g}, \mathrm{Na}=11 \mathrm{mg} / \mathrm{g}$ and $\mathrm{K}=13 \mathrm{mg} / \mathrm{g}$ ). In CR2, elemental concentrations decrease between the bottom sample $(\mathrm{Si}=340 \mathrm{mg} / \mathrm{g}, \mathrm{Al}=250 \mathrm{mg} / \mathrm{g}$ and $\mathrm{K}=23 \mathrm{mg} / \mathrm{g})$ and $50 \mathrm{~cm}(\mathrm{Si}=9 \mathrm{mg} / \mathrm{g}, \mathrm{Al}=2 \mathrm{mg} / \mathrm{g}$ and $\mathrm{K}=0.14 \mathrm{mg} / \mathrm{g}$ ). Values are low and stable between $50 \mathrm{~cm}$ and $105 \mathrm{~cm}$, then increase towards $122 \mathrm{~cm}$ and finally decrease towards the surface. Most of the Na values are below the detection limit in CR2.

\subsection{Selected contaminant metals}

In $\mathrm{CR} 1, \mathrm{Zn}$ and $\mathrm{Pb}$ profiles display a similar pattern (Table 1). Between 0 and $70 \mathrm{~cm}, \mathrm{Zn}$ is below the detection limit while $\mathrm{Pb}$ concentrations are low $(6 \mu \mathrm{g} / \mathrm{g}<\mathrm{Pb}<13.7 \mu \mathrm{g} / \mathrm{g})$. A significant amount of $\mathrm{Zn}$ occurs at $70 \mathrm{~cm}(49 \mu \mathrm{g} / \mathrm{g})$ while the $\mathrm{Pb}$ content increases to reach $41 \mu \mathrm{g} / \mathrm{g}$ at $70 \mathrm{~cm}$. 
Table 3

The ${ }^{14} \mathrm{C}$ dates on 6 samples from CR1. Three samples $(74-76 \mathrm{~cm}, 76-78 \mathrm{~cm}$ and $78-80 \mathrm{~cm}$ height) are a mix of two $1 \mathrm{~cm}$-thick slices

\begin{tabular}{|c|c|c|c|c|c|}
\hline $\begin{array}{l}\text { Height } \\
(\mathrm{cm})\end{array}$ & $\begin{array}{l}{ }^{14} \mathrm{C} \\
\text { date }\end{array}$ & Uncertainty & $\begin{array}{l}\text { Calibrated ages Oxcal (Bronk Ramsey, 2001) } \\
\text { version } 3.10(2005)\end{array}$ & $\begin{array}{l}\text { Calibrated ages Bpeat wiggle-matching (Blaauw and } \\
\text { Christen, 2005) }\end{array}$ & Lab no. \\
\hline $82-83$ & 1625 & 30 & AD 350-540 & - & $\begin{array}{l}\text { Poz- } \\
11552\end{array}$ \\
\hline $80-81$ & 1765 & 30 & AD $130-380$ & AD 152-328 & $\begin{array}{l}\text { Poz- } \\
11378\end{array}$ \\
\hline $78-80$ & 1810 & 60 & AD 70-380 & AD 131-258 & $\begin{array}{l}\text { GrN- } \\
29298\end{array}$ \\
\hline $76-78$ & 1860 & 50 & AD 50-320 & AD 86-214 & $\begin{array}{l}\text { GrN- } \\
29297\end{array}$ \\
\hline $74-76$ & 1930 & 40 & BC 40-AD 210 & AD 19-200 & $\begin{array}{l}\text { GrN- } \\
29296\end{array}$ \\
\hline $10-11$ & 4580 & 50 & BC $3510-3090$ & - & $\begin{array}{l}\text { GrN- } \\
29473\end{array}$ \\
\hline
\end{tabular}

The calibrated age intervals in bold are used in the discussion.

From $70 \mathrm{~cm}$ to $78 \mathrm{~cm}$, concentrations of both elements increase drastically $(41 \mu \mathrm{g} / \mathrm{g}<\mathrm{Pb}<77 \mu \mathrm{g} / \mathrm{g}, 49 \mu \mathrm{g} / \mathrm{g}<\mathrm{Zn}<$ $1037 \mu \mathrm{g} / \mathrm{g})$. Concentrations then decrease towards $81.5 \mathrm{~cm}(\mathrm{~Pb}=10.9 \mu \mathrm{g} / \mathrm{g}, \mathrm{Zn}=114 \mu \mathrm{g} / \mathrm{g})$ and peak twice, at $85.5 \mathrm{~cm} \quad(\mathrm{~Pb}=33 \mu \mathrm{g} / \mathrm{g}, \quad \mathrm{Zn}=517 \mu \mathrm{g} / \mathrm{g}) \quad$ and $93.5 \mathrm{~cm}$ $(\mathrm{Pb}=42 \mu \mathrm{g} / \mathrm{g}, \mathrm{Zn}=792 \mu \mathrm{g} / \mathrm{g})$, respectively. From $98 \mathrm{~cm}$ to the surface, the $\mathrm{Zn}$ concentration decreases while that of $\mathrm{Pb}$ increases strongly. In CR2, Pb concentrations vary between 6.8 and $30.6 \mu \mathrm{g} / \mathrm{g}$ from $0 \mathrm{~cm}$ to $110 \mathrm{~cm}$. From $111 \mathrm{~cm}, \mathrm{~Pb}$ values increase and reach around $600 \mu \mathrm{g} / \mathrm{g}$ at $123.5 \mathrm{~cm}$. Zinc is below the detection limit between 10 and $95 \mathrm{~cm}$, except in the bottom sample $(5 \mu \mathrm{g} / \mathrm{g})$. Then $\mathrm{Zn}$ concentrations increase from $111 \mathrm{~cm}$ to $123.5 \mathrm{~cm}$ to reach $940 \mu \mathrm{g} / \mathrm{g}$ at $123 \mathrm{~cm}$. The $\mathrm{Zn}$ profile also displays three peaks at $97.5 \mathrm{~cm}(20 \mu \mathrm{g} / \mathrm{g}), 102.5 \mathrm{~cm}(53 \mu \mathrm{g} / \mathrm{g})$ and $109.5 \mathrm{~cm}(76 \mu \mathrm{g} / \mathrm{g})$, respectively.

\subsection{Lead isotopes}

Table 2 summarises results of $\mathrm{Pb}$ isotope analyses. In CR1 (Table 2), ${ }^{208} \mathrm{~Pb} /{ }^{204} \mathrm{~Pb},{ }^{207} \mathrm{~Pb} /{ }^{204} \mathrm{~Pb}$ and ${ }^{206} \mathrm{~Pb} /{ }^{204} \mathrm{~Pb}$ isotopic ratios decrease from the bottom (respectively, $38.9589 \pm 0.0153,15.7012 \pm 0.0057$ and $19.1661 \pm 0.0071)$ to $70.5 \mathrm{~cm}$ (respectively, $38.3883 \pm 0.0149,15.6268 \pm$ 0.0057 and $18.3984 \pm 0.0072$ ). From $70.5 \mathrm{~cm}$ to $98.5 \mathrm{~cm}$ values are stable (respectively, between $38.3120 \pm 0.0106$ and 38.3991 \pm 0.0177 , between $15.6236 \pm 0.0041$ and $15.6288 \pm 0.0068$ and between $18.3299 \pm 0.0053$ and $18.4255 \pm 0.0067$ ) except in sample $81.5 \mathrm{~cm}$ which displays higher values (respectively, 38.6681 \pm 0.0208 , $15.6603 \pm 0.0079$ and $18.7404 \pm 0.0081)$. The sample located near the surface presents the lowest values (respectively, $38.1746 \pm 0.0169,15.6117 \pm 0.0067$ and $18.1879 \pm$ 0.0079).

In $\mathrm{CR} 2,{ }^{208} \mathrm{~Pb} /{ }^{204} \mathrm{~Pb},{ }^{207} \mathrm{~Pb} /{ }^{204} \mathrm{~Pb}$ and ${ }^{206} \mathrm{~Pb} /{ }^{204} \mathrm{~Pb}$ isotopic ratios decrease from $50 \mathrm{~cm}$ (respectively, $38.8087 \pm$ $0.0113,15.6872 \pm 0.0036$ and $19.0550 \pm 0.0043$ ) towards the surface $(38.0000 \pm 0.0098, \quad 15.5952 \pm 0.0039$ and $18.0354 \pm 0.0053)$.

\subsection{Radiocarbon dates}

Results were calibrated using Oxcal 3.10 (Bronk Ramsey, $2001)$ and four selected dates (74-76, 76-78, 78-80 and
$80-81 \mathrm{~cm}$ ) were wiggle-matched using a Bayesian approach developed for peat in the calibration tool Bpeat (Blaauw and Christen, 2005). The data set is coherent even if intervals are partly overlapping in the Bpeat-calibrated samples (Table 3 ). This overlap is due to (1) the continuity of sampling for ${ }^{14} \mathrm{C}$ dating and (2) the high compaction of the peat making a $1 \mathrm{~cm}$-thick slice to represent several tens of years. Therefore, there is an overlap which is however chronologically ordered. For example, sample GrN29296 $(74-76 \mathrm{~cm})$ displays the oldest probablility age of AD 19 and the youngest probability of AD 200. The directly above sample GrN29297 (76-78 cm height) displays the oldest probablility age of $A D 86$ (i.e. younger than $A D 19$ ) and the youngest probability of $A D 214$ (i.e. younger than $A D$ 200). The same goes between GrN29297 (76-78 cm height) and GrN29298 (78-80 cm height), and between GrN29298 (78-80 cm height) and Poz11378 (80-81 cm height). Bcal Bayesian approach (Buck et al., 1996) was also tested (results not reported here) but did not improve the results from Bpeat. Calibration using Bpeat provided smaller intervals. In the following discussion, these Bpeat-calibrated age dates will therefore be used together with the oxcal-calibrated age dates of the two other samples.

\section{Discussion}

\subsection{Environmental impact}

\subsubsection{Building and use of the road}

Geochemical analyses provide clear documentation not only about the impact of the road on the surrounding environment, but also about one of its possible purposes, namely ore transport. Sudden increases in Si concentrations in both peat columns show a direct impact of the building and the regular use of the road. The first significant Si concentrations occur at 81.5 and $106.5 \mathrm{~cm}$ height, respectively in CR1 and CR2 (Fig. 3). The Al, Na and K profiles also follow the same trend. Careful observation of thin sections from these depth intervals reveals a strong contamination of the peat by numerous Revinian quartzite particles used to cobble the road. This material is therefore assumed to have been produced during the construction and the use of the road. Absolute concentration discrepancies are explained by the water stream causing preferential 

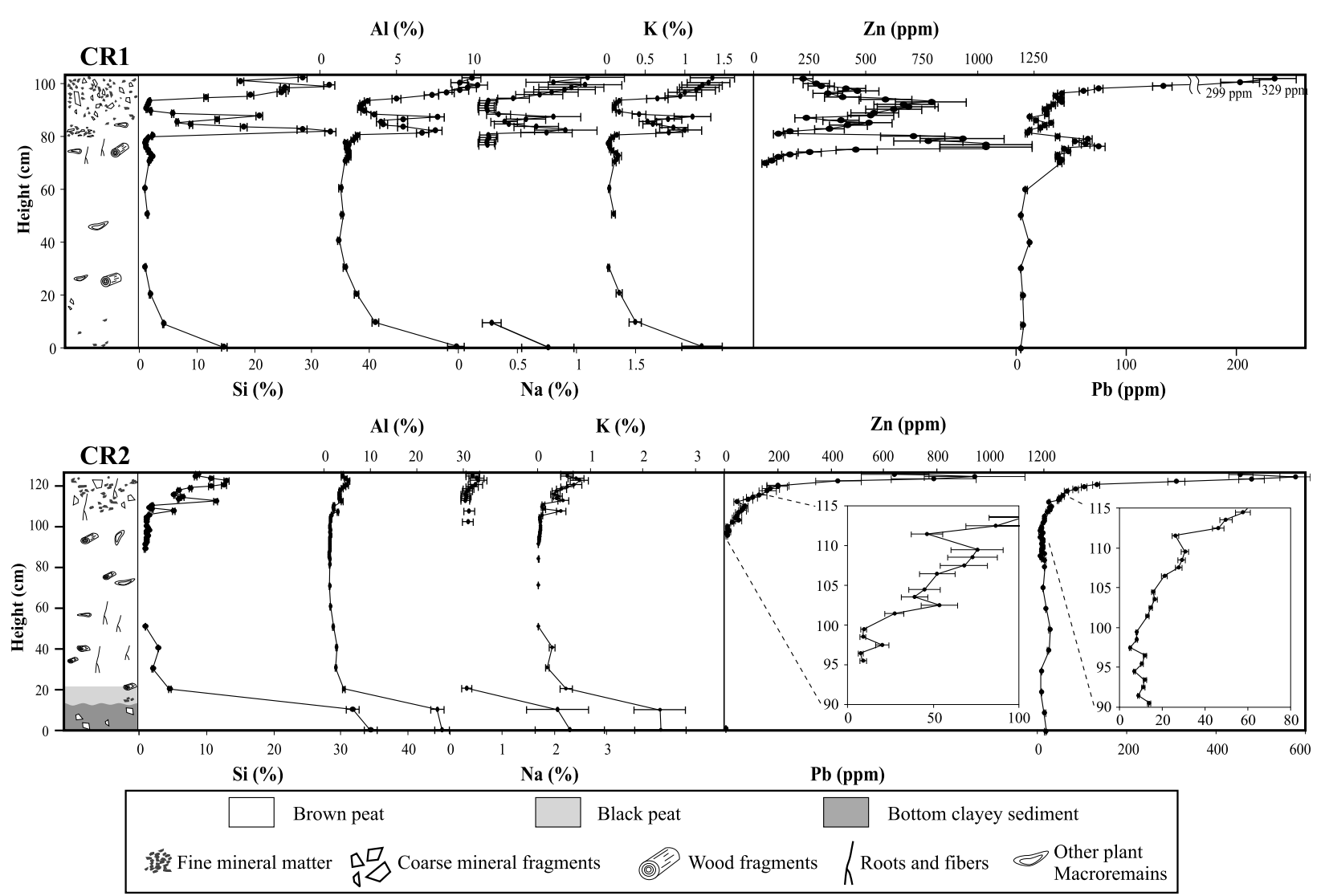

Fig. 3. Selected elemental concentrations (major + trace elements) in CR1 and CR2. Lithological information is based on microscopic observation on thin sections. 


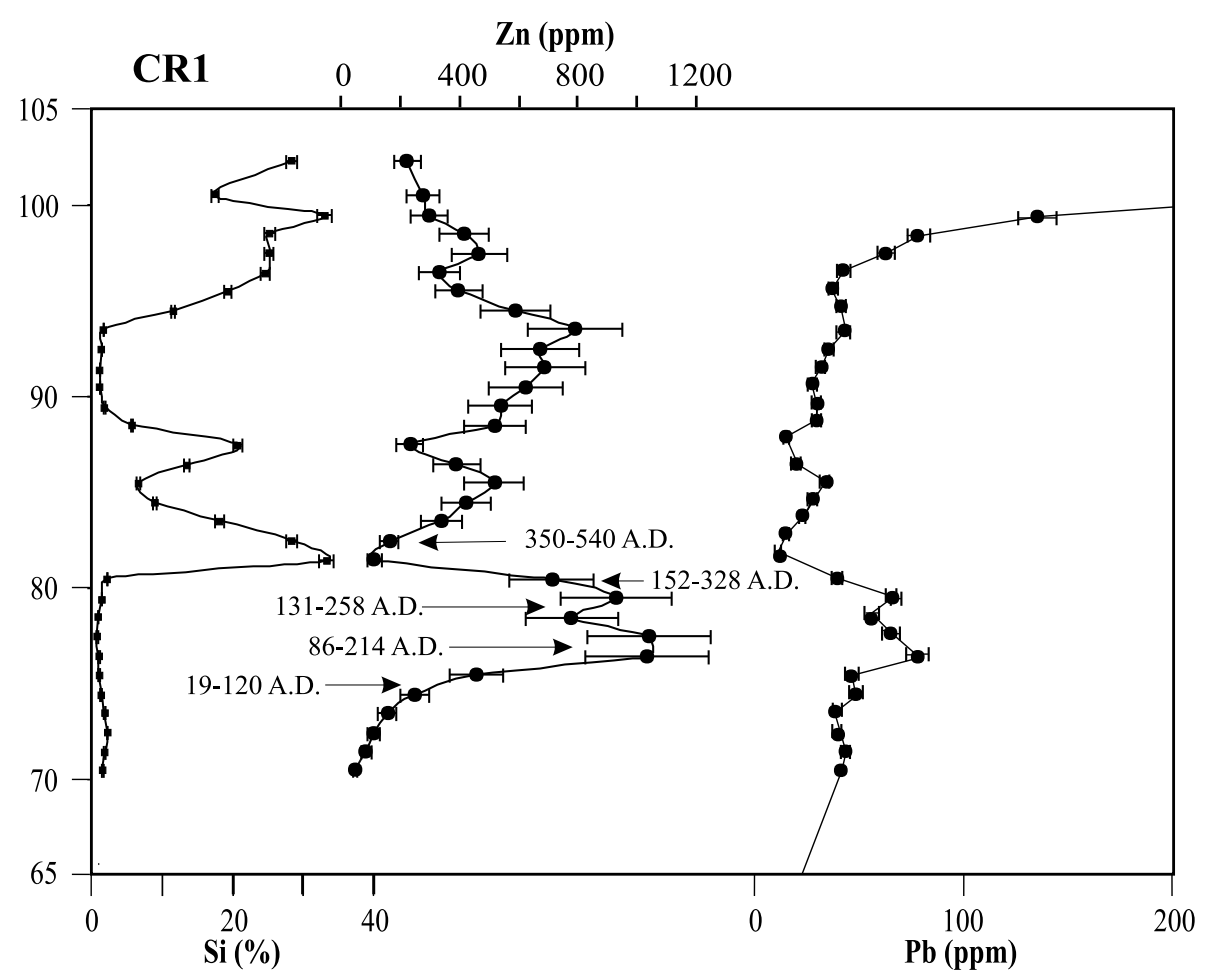

Fig. 4. The ${ }^{14} \mathrm{C}$ based chronology performed on the CR1 profile (see text for details).

accumulation to the eastern side of the road. The sample below $(80.5 \mathrm{~cm})$ and the sample above $(82.5 \mathrm{~cm})$ the $\mathrm{Si}$ peak were respectively dated at AD 152-328 and AD 350-540 (Fig. 4). The youngest date indicates that the road was already cobbled before AD 350-540. The oldest date must be interpreted cautiously due to the random mode of particle deposition and the lack of information about the time span between the cobbling and the first particle accumulation. However, it seems reasonable to assume that this accumulation started as soon as the cobbling was realized, i.e. during or after AD 152-328.

Higher $\mathrm{Pb}$ and $\mathrm{Zn}$ concentrations suggest a strong local pollution possibly beginning between AD 19 and AD 120 and peaking between AD 86 and AD 328. (Fig. 4). Particular levels (between $81 \mathrm{~cm}$ and $84 \mathrm{~cm}$, and between $86 \mathrm{~cm}$ and $88 \mathrm{~cm}$ height, respectively) display low $\mathrm{Zn}$ and $\mathrm{Pb}$ content due to the important amount of quartzite fragments, increasing the $\mathrm{Si}$ signal and diluting the $\mathrm{Pb}$ and $\mathrm{Zn}$ concentrations. In Belgium, $\mathrm{Pb}$ and $\mathrm{Zn}$ concentrations have been previously measured in a core from a nearby ombrotrophic peat bog (De Vleeschouwer et al., 2007). This record displays quite similar $\mathrm{Pb}$ concentrations $(40 \mu \mathrm{g} /$ $\mathrm{g}<\mathrm{Pb}<100 \mu \mathrm{g} / \mathrm{g}$ ) during the same time span, possibly reflecting the $\mathrm{Pb}$ pollution found here. However, $\mathrm{Zn}$ concentrations are often very low $(8 \mu \mathrm{g} / \mathrm{g}<\mathrm{Zn}<35 \mu \mathrm{g} / \mathrm{g})$ or below the detection limit, excepted in AD $1950{ }^{210} \mathrm{~Pb}-\mathrm{da}-$ ted peat layers where $\mathrm{Zn}$ peaks at $250 \mu \mathrm{g} / \mathrm{g}$. This value is still 4 times less than the one found beside the cobbled road. A study carried out by Kempter (1996) in another nearby ombrotrophic bog showed no particular enrichment in $\mathrm{Zn}$ or $\mathrm{Pb}$ during the first five centuries $\mathrm{AD}$. It can therefore be concluded that the peat aside the cobbled road has recorded a very local $\mathrm{Pb}$ and $\mathrm{Zn}$ pollution. Such pollution is likely to be from the transport of $\mathrm{Pb}-\mathrm{Zn}$-rich material on the road.

\subsubsection{Sources of pollution}

Lead isotopes are used to discriminate between possible $\mathrm{Pb}$ sources, especially at the highly $\mathrm{Pb}-\mathrm{Zn}$-polluted levels. Lead isotopic data define two trend lines (Fig. 5). The right (i.e. higher ${ }^{206} \mathrm{~Pb} /{ }^{207} \mathrm{~Pb}$ and lower ${ }^{208} \mathrm{~Pb} /{ }^{206} \mathrm{~Pb}$ ratios) trendline is defined by the Verviers Pb-Zn ores (Pasteels et al., 1980; Cauet et al., 1982; Dejonghe, 1998) and a crustal (i.e. non anthropogenic) source. This crustal source differs significantly from the mean upper continental crust values defined by several authors (Asmerom and Jacobsen, 1993; Hemming and McLennan, 2001; Millot et al., 2004). It fits rather better with the Belgian pre-industrial background values proposed by Sonke et al. (2002) and De Vleeschouwer et al. (2007). The left trendline is defined by the Verviers $\mathrm{Pb}-\mathrm{Zn}$ ores and the recent (1994-1999) urban aerosols from nearby Germany and The Netherlands (Bollhöfer and Rosman, 2001).

In section CR1, samples from the lower part of the peat column $(9.5 \mathrm{~cm}$ and $40.5 \mathrm{~cm})$ show that the main inorganic inputs to these layers derive from the regional soil and rock erosion as their isotopic signatures are in good agreement with the Belgian pre-industrial background. Samples situated in the highly $\mathrm{Zn}$ - and $\mathrm{Pb}$-contaminated interval (i.e. $60-99 \mathrm{~cm}, n=8$ ) are all centred upon the isotopic field of the $\mathrm{Pb}-\mathrm{Zn}$ ores of the Verviers syncline, located $15 \mathrm{~km}$ northwards of the excavation site. This observation is in good agreement with the hypothesis that this road was used for ore transport. The sample from $81.5 \mathrm{~cm}$ shows a lower ${ }^{208} \mathrm{~Pb} /{ }^{206} \mathrm{~Pb}$ ratio and a higher ${ }^{206} \mathrm{~Pb} /{ }^{207} \mathrm{~Pb}$ ratio that can be explained by the occurrence of quartzite fragments 


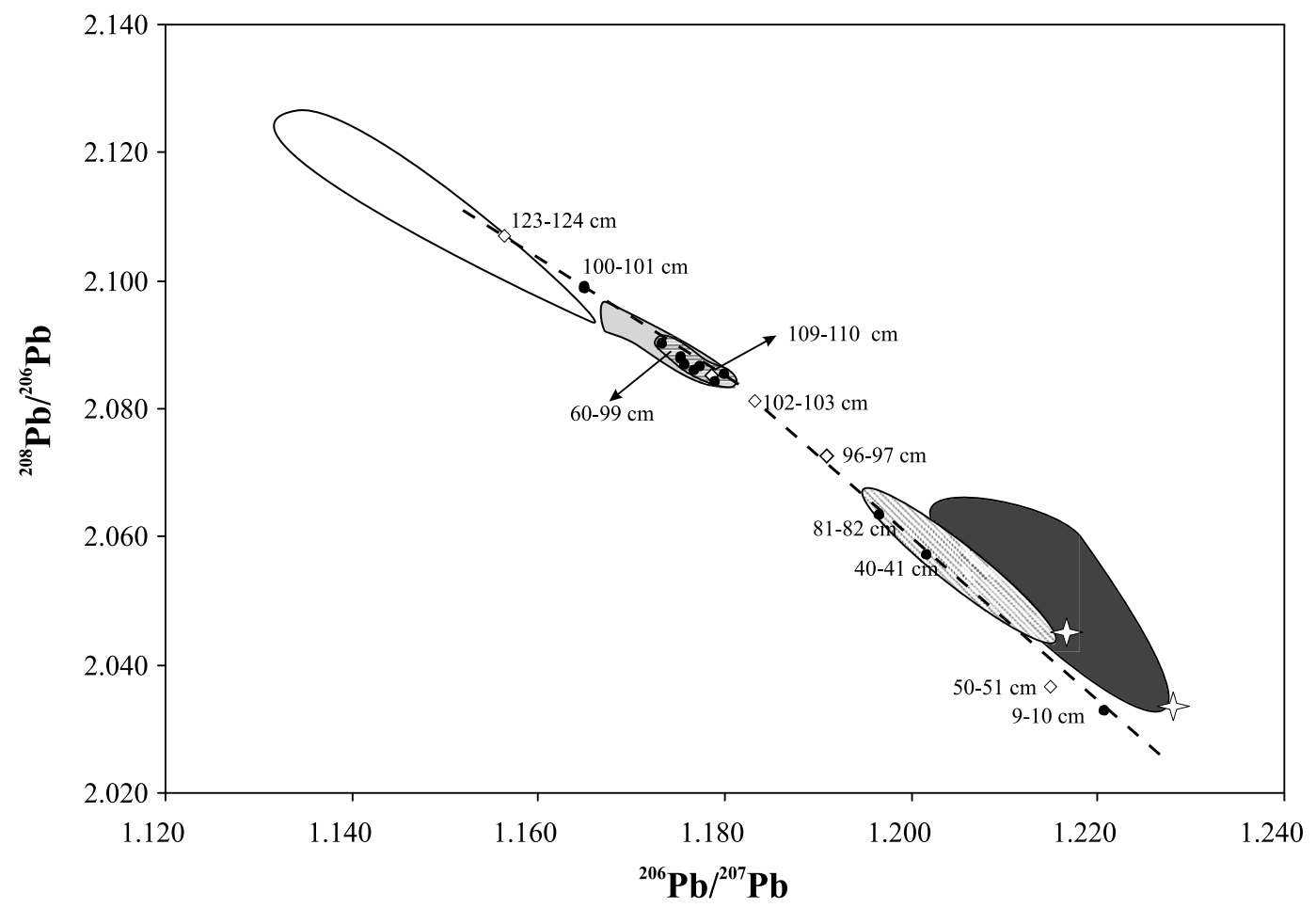

Fig. 5. ${ }^{208} \mathrm{~Pb} /{ }^{206} \mathrm{~Pb} v s .{ }^{206} \mathrm{~Pb} /{ }^{207} \mathrm{~Pb}$ isotopic biplot. Black dots and white diamonds are samples from CR1 and CR2, respectively. The error ranges are smaller than the symbols. Horizontal dashed field encompasses samples of CR1 between $60-99 \mathrm{~cm}$ height (i.e. eight samples with very high $\mathrm{Zn}$ and high Pb contents). White field (13 points) represents the modern aerosols from Belgium, nearby Germany and The Netherlands (Bollhöfer and Rosman, 2001). Light grey field (18 points) represents the nearby (less than $10 \mathrm{~km}$ ) Pb-Zn ores from the Verviers syncline (Cauet et al., 1982; Dejonghe, 1998). Dark grey field (4 points) represents the Upper Continental Crust (Millot et al., 2004; Hemming and McLennan, 2001; Grousset et al., 1994; Asmerom and Jacobsen, 1993). Oblique dashed area represents the Belgian pre-industrial background proposed by Sonke et al. (2002). White stars are the local pre-industrial background in Belgian peat proposed by De Vleeschouwer et al. (2007).

(with a crustal $\mathrm{Pb}$ isotopic signature). The uppermost peat sample $(100.5 \mathrm{~cm})$ displays a signature in good agreement with modern aerosols.

Samples from CR2 display the same trend. Samples at $50.5 \mathrm{~cm}$ and $96.5 \mathrm{~cm}$ height show isotopic ratios similar to the Belgian pre-industrial background. Samples at $102.5 \mathrm{~cm}$ and $109.5 \mathrm{~cm}$ (i.e. samples with $\mathrm{Pb}-\mathrm{Zn}$ contamination) display $\mathrm{Pb}$ isotopic ratios in good agreement with the Verviers $\mathrm{Pb}-\mathrm{Zn}$ ores field. This again favours the hypothesis of ore transport on the road. The uppermost (i.e. recent) sample shows $\mathrm{Pb}$ isotopic ratios similar to modern aerosols.

\subsubsection{Post-depositional mobility of contaminant metals}

The archaeological findings presented here are for the area located down slope on a peatland where surface runoff was observed during the sampling. Punctual inorganic inputs are thus likely. The question of whether these phenomena could affect the geochemistry of the peat must therefore be assessed.

Investigations of pollution history in peat are usually achieved in ombrotophic bogs, (e.g. West et al., 1997; Shotyk et al., 1998; Martínez-Cortizas et al., 1997, 2002; Nieminen et al., 2002; Mighall et al., 2002; Le Roux et al., 2004a; De Vleeschouwer et al., 2007). However, a few studies have demonstrated the potential of minerotrophic peat to record past geochemical changes, either natural or anthropogenic, (e.g. West et al., 1997; Shotyk, 2002; Baron et al., 2005). In addition, the knowledge of local pol- lution sources is of high interest to accurately reconstruct global contaminant metal pollution (Baron et al., 2005). Lead has been used as an atmospheric pollution tracer in several geochemical studies in peat bogs, (e.g. MartínezCortizas et al., 1997; Shotyk et al., 1998; Mighall et al., 2002). Most authors have considered $\mathrm{Pb}$ as being immobile in ombrotrophic peat (Shotyk et al., 1998, 2000; Mighall et al., 2002; Martínez-Cortizas et al., 1997; Jones and Hao, 1993) and in some cases also in minerotrophic peat (Shotyk, 2002). Elevated amounts of $\mathrm{Pb}$ were therefore considered as contemporaneous of the level that records it.

Zinc mobility in peat is however still under debate. Its distribution is linked, among others, to bioaccumulation, water table fluctuation and pH conditions (Shotyk, 1988). Zinc distribution can also be linked to the type of vegetation as different parts of the same plant can concentrate $\mathrm{Zn}$ in different ways (Livett et al., 1979). Zinc seems to be more mobile than $\mathrm{Pb}$ and therefore more likely to be leached (Livett et al., 1979). Recently, Weiss et al. (2007) have demonstrated Zn mobility in peat cores from Finnish natural and polluted sites. They suggest that $\mathrm{Zn}$ is affected by multiple biogeochemical processes. They therefore recommand that these processes have to be taken into account before using $\mathrm{Zn}$ as a tracer of pollution. However, even more recently, Sonke et al. (2008) have found deep Zn and $\mathrm{Pb}$ peaks in organic sediment from Belgium. They correlate these peaks with the well known history of local $\mathrm{Zn}$ and $\mathrm{Pb}$ smelting. They concluded, conversely to Weiss et al. (2007) that $\mathrm{Zn}$ is not subject to vertical migration. 
Despite this debate, $\mathrm{Zn}$ is regularly used to trace pollution history linked to mining activities, but explanations depend on the context. Mighall et al. (2002) studied pollution history linked to the $\mathrm{Pb}-\mathrm{Zn}$ ore mining in a blanket peat. In their study, Pb concentrations were in good agreement with the mining activities history. Zinc concentrations could therefore also reflect mining activities. However, the authors suggested caution as the data showed possible re-mobilization which may have blured the actual boundaries of deposition. West et al. (1997) studied the pollution history linked to the mining of various (including $\mathrm{Pb}$ and $\mathrm{Zn}$ ) ores. Concentration patterns and enrichment factors were interpreted as reflecting the regional pollution but elemental mobility was not discussed. Jones and Hao (1993) measured major and trace element concentrations in peat. The resulting statistical treatment showed that $\mathrm{Zn}$ and $\mathrm{Pb}$ were strongly correlated. They showed the same pattern, most likely indicating anthropogenic impact, and were at their initial level of deposition. In this peat bog, $\mathrm{Zn}$ was not mobilized. From this brief overview, it could be concluded that $\mathrm{Pb}$ is the best indicator and that $\mathrm{Zn}$ can be a good second element to trace past pollution.

In the peat columns studied here, post-depositional mobilization of $\mathrm{Pb}$ and $\mathrm{Zn}$ is unlikely. Indeed, samples with high $\mathrm{Zn}$ and $\mathrm{Pb}$ content (CR1 between 60 and $99 \mathrm{~cm}$ excluding the $80.5 \mathrm{~cm}$ sample) fit within a narrow range of $\mathrm{Pb}$ isotopic ratios (Fig. 5). Moreover, all these ratios fall within the field of Verviers syncline $\mathrm{Pb}-\mathrm{Zn}$ ores. If any mobilization of $\mathrm{Pb}$ from samples above the first $\mathrm{Si}$ peak had occurred, a progressive decrease of $\mathrm{Pb}$ and $\mathrm{Zn}$ content down-core would have been expected, together with a mixed $\mathrm{Pb}$ isotopic signature between Verviers ores and Belgian pre-industrial background. This is clearly not observed here. The stability of $\mathrm{Pb}$ isotopic ratios has already been used by Baron et al. (2005) as an argument to attest to $\mathrm{Pb}$ immobility in fen (i.e. minerotrophic) peat in France. Moreover, $\mathrm{Pb}$ and $\mathrm{Zn}$ display a high degree of correlation $\left(R^{2}=0.88\right)$ in CR1 between 76 and $94 \mathrm{~cm}$. This suggests a common origin and deposition process for $\mathrm{Pb}$ and $\mathrm{Zn}$. It also favours the immobility of both elements.

\subsubsection{Early mining activities and purpose of the road}

In conjunction with more conventional road uses, e.g. civilian and military movement, trade routes, etc. geochemical investigations carried out here provide clear evidence for the road being used for the transport of local $\mathrm{Pb}$ and $\mathrm{Zn}$ ores from the Verviers syncline. These ores are known to have been mined from the 14th century (Dejonghe and Ladeuze, 1993). Although the extraction of $\mathrm{Pb}-\mathrm{Zn}$ ores of the Verviers syncline during Roman or even Celtic times is mentioned in the literature (Dejonghe, 1998; Ladeuze et al., 1991), it only refers to Plini (1953) who vaguely mentioned that an ore called Cadmia was extracted in "Germania". No more precise location was mentioned. In addition, there is no archaeological, palynological or geochemical evidence attesting to an early mining of $\mathrm{Pb}$ and $\mathrm{Zn}$ or smelting activities in East Belgium. However, various archaeological artefacts found in and around the Hautes Fagnes area (Gilot, 1977; Dumont, 1979, 1980;

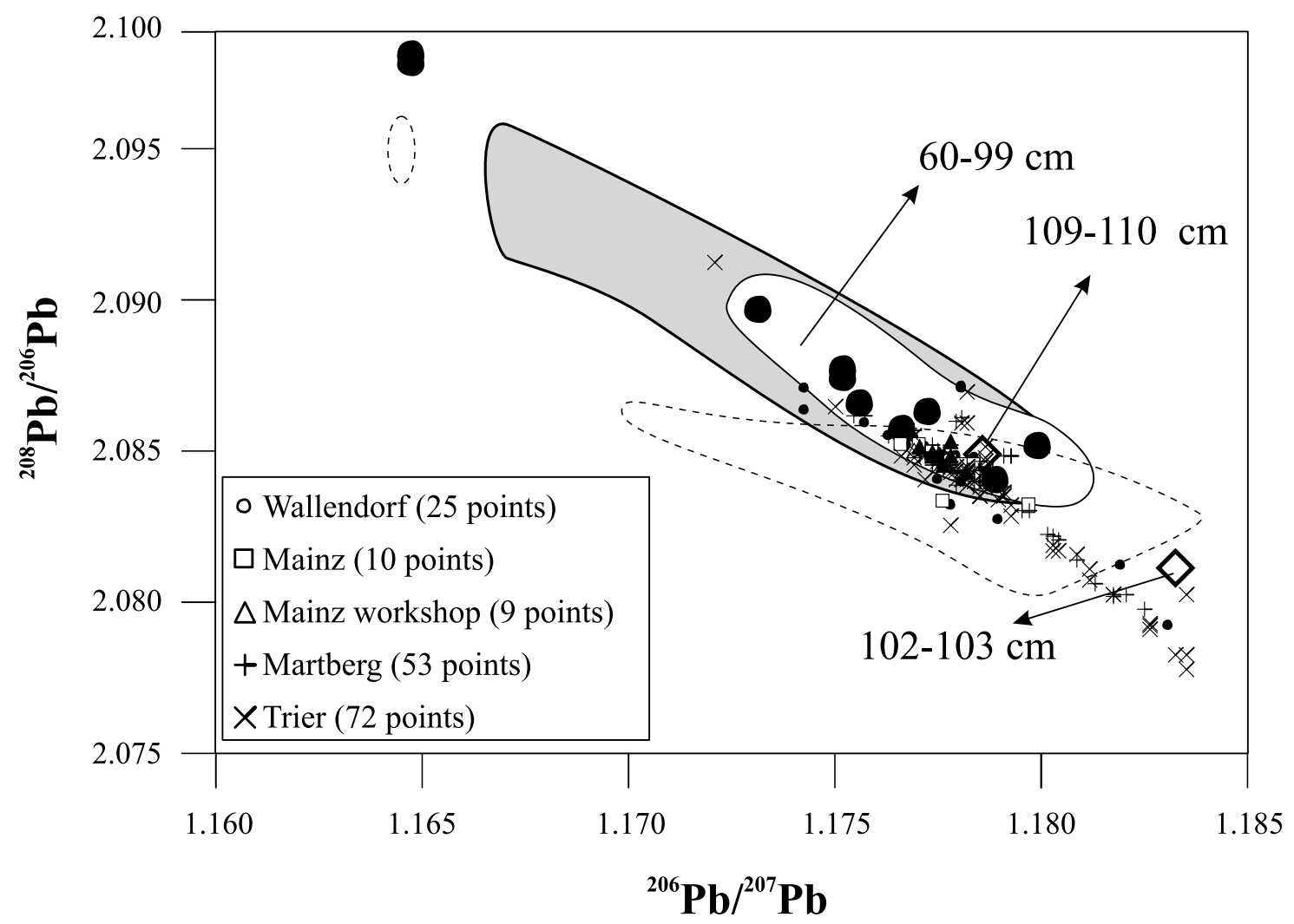

Fig. 6. ${ }^{208} \mathrm{~Pb} /{ }^{206} \mathrm{~Pb}$ vs. ${ }^{206} \mathrm{~Pb} /{ }^{207} \mathrm{~Pb}$ isotopic biplot showing data from CR1 (black circles) and CR2 (white diamonds) compared to isotopic signatures of Verviers Pb-Zn ores (grey shaded area), German Eifel Pb ores (dashed line areas, after Durali-Mueller et al., 2007) and German Pb artefacts (enclosed symbols) from various locations (after Durali-Mueller et al., 2007). The error ranges are smaller than the symbols. 
Remy, 1981; Cauuet, 2005), like alluvial mounds remaining from Au prospecting (ranging from BC 120 - AD 140 to BC 400-200), graves, coins and remains of cities and villages, attest to an early occupation. The increasing anthropogenic impact of local population is also recorded by increases in Plantago lanceolata and cereal pollen in dated peat cores (Damblon, 1994; Gotjé et al., 1990).

The dataset presented here, especially the strong $\mathrm{Pb}$ isotopic similarity between contaminated peat layers and local ores, may therefore represent the first evidence for ore mining during early Roman to Merovingian times. Together with the high elemental concentrations in $\mathrm{Pb}$ and $\mathrm{Zn}$, it can also be assumed that these ores were transported on the road across the Hautes Fagnes.

As mentioned in Section 1, Trier has already been considered to be the destination of the road. This city is known to have been a Late Roman capital, a major centre of coinage (Sutherland, 1967), a key crossroad and a fluvial point. Numerous $\mathrm{Pb}$ artefacts have been found in archaeological excavations in this area. Several of them have been investigated for their $\mathrm{Pb}$ isotopic ratios by Durali-Mueller et al. (2007), together with artefacts from other nearby locations (Mainz, Wallendorf, Martberg) west to the Rhine river. Lead isotopic signatures of these artefacts correspond to the signatures of German Pb ores. However, Pb isotopic ra- tios of these artefacts also show an important overlap with the data presented here and with the isotopic signatures of Verviers $\mathrm{Pb}-\mathrm{Zn}$ ores (Fig. 6). As strong $\mathrm{Pb}-\mathrm{Zn}$ pollution is encountered in the peat near the road during late Roman times, Belgian $\mathrm{Pb}-\mathrm{Zn}$ ores must have therefore been mined and transported towards Germany and may also have used in the fabrication of various $\mathrm{Pb}$ objects in the Trier area. Moreover, several $\mathrm{Cu}$ ore deposits were also found around this city (Fig. 7). Romans are known to have made some of their coins and other objects with brass (Halleux, 2005), which is a $\mathrm{Zn}-\mathrm{Cu}$ alloy. Assembling all this information, it seems legitimate to propose that $\mathrm{Zn}$ and $\mathrm{Pb}$ ores were mined in the Verviers syncline and transported through the Hautes Fagnes towards Trier.

As $\mathrm{Pb}$ and $\mathrm{Zn}$ peaks are considered to reflect ore transport, the time interval of AD 86-328 provides a minimum age-date for this transport and its impact on the peat. It fits clearly within Roman times (see Fig. 4) and is in good agreement with the suggestion developed above. However, the road was probably not cobbled before AD 152-328 (see Section 5.1.1). Such a discrepancy between ore transport (attested by the first $\mathrm{Pb}-\mathrm{Zn}$ contamination) and the cobbling (attested by the first Si contamination) may be due either to the random quartzite deposition mode, or to an effective ore transport on an early non-cobbled road. How-

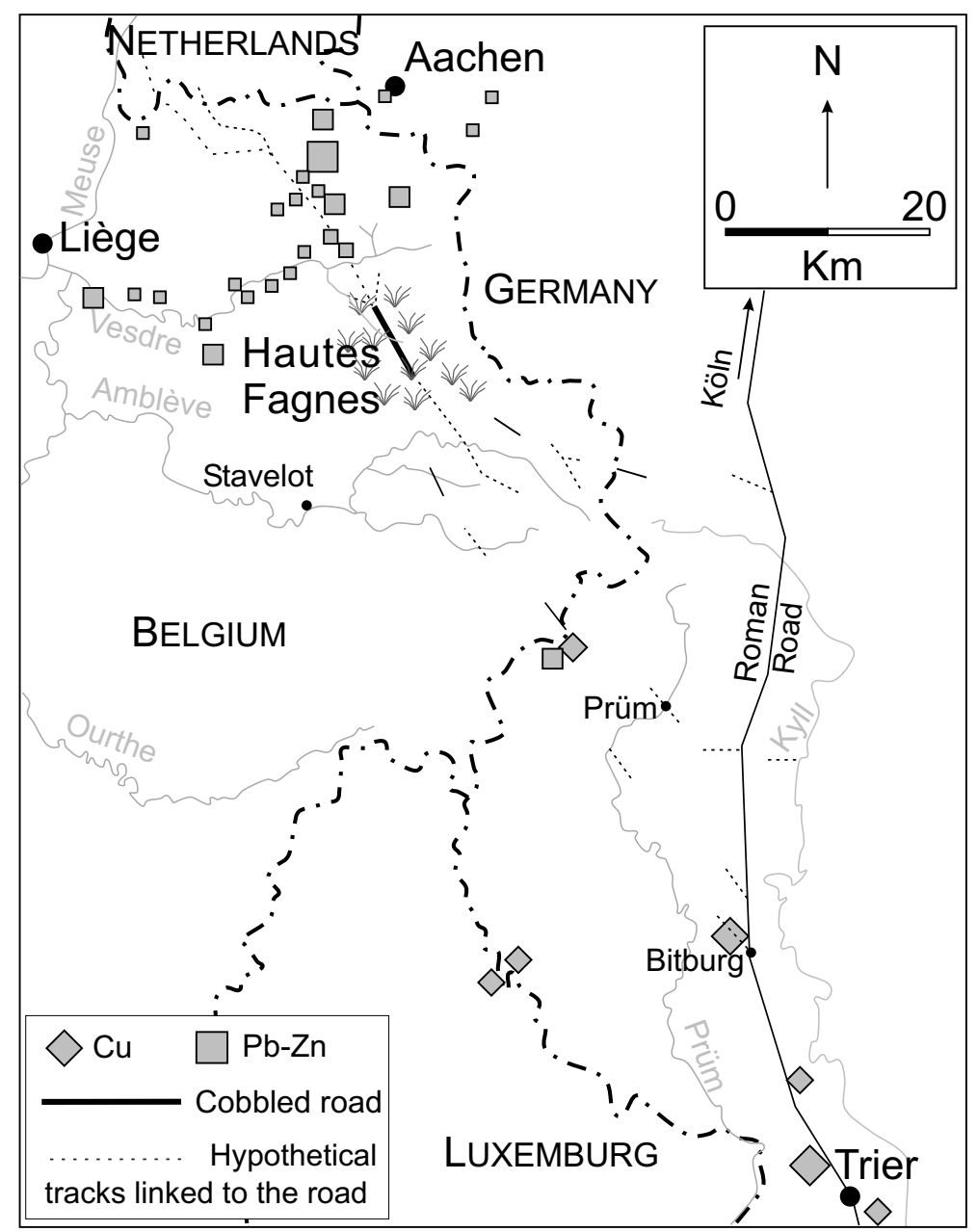

Fig. 7. The cobbled road in the historical and geographical context. Principal $\mathrm{Cu}, \mathrm{Zn}$ and $\mathrm{Pb}$ ores are also reported. (modified after Corbiau, 1981b and Permingeat et al., 1964). 
ever, due to the large overlap between each age interval, the present data do not allow distinguishing between the two hypotheses. Archaeological investigations are still ongoing and might provide additional support for the chronology of the road construction.

\section{Conclusions}

The geochemical investigation of peat columns collected alongside an ancient cobbled road in SE-Belgium documents the road's impact on the local environment but also provides new perspectives for future geoarchaeological research in general.

At a local scale, the investigation shows that: (1) high contents of $\mathrm{Si}, \mathrm{Al}, \mathrm{Na}$ and $\mathrm{K}$ reflect early peat pollution when cobbles and finer material were eroded during the building and use of the road; (2) the precise date of the road cobbling is still unclear. However, the occurrence of mineral particles in the peat evidence the presence of the cobbled road just before AD 350-540 and probably not before AD 152-328; (3) the mineral pollution is also preceded by a $\mathrm{Pb}-\mathrm{Zn}$ pollution. Lead isotopic ratios reveal that the road served, among other things, to transport $\mathrm{Pb}-\mathrm{Zn}$ ores from nearby Verviers $\mathrm{Pb}-\mathrm{Zn}$ ore deposits.

It is therefore concluded that the onset of ore transport started during the early Roman times. This time frame is in good agreement with other archaeological evidence of Roman activities in the area. Geochemical findings from this study also support that the Belgian $\mathrm{Pb}-\mathrm{Zn}$ ores from Verviers syncline could have been mined as early as during early Roman times. It is therefore suggested that in similar studies, the local isotopic source should be taken into consideration when dealing with past pollution reconstruction for this time period.

More generally, $\mathrm{Zn}$ is apparently immobile in the profiles, due to its similar behaviour to $\mathrm{Pb}$. Moreover, the preservation of an ancient road and its environmental impact in a peatland also provides the unique opportunity to directly trace palaeopollution close to an archaeological site using geochemistry. More interest should be taken on similar ancient roads or other archaeological sites, in terms of their possible impact on the immediate environment.

This study demonstrates how geochemistry can be successfully applied to an archaeological problem. Geochemistry can indeed be used as a tool to investigate small scale changes in peat columns and to provide conclusion in terms of ore mining, routes and trade, and therefore to give insights to solve historical problems.

\section{Acknowledgements}

We warmly thank Marie-Hélène Corbiau (Direction de l'Archéologie du Ministère de la Région Wallonne) for providing an easy access to the archaeological site. We are grateful to Guy Bologne and Sophie Leclercq for the XRF analyses, J-P Cullus and F. Boulvain for thin section preparation, and to Maarten Blaauw (Queen's University, Belfast) for his fruitful comments on the age-dating. This manuscript benefited from constructive reviews by Tim Mighall and Gaël Le Roux. We thank Ron Fuge for the editorial handling of the manuscript, Philippe Claeys (Vrije Universiteit Brus- sel) for comments on an earlier version of this manuscript and Maria Gehrels (Univ. Plymouth, UK) for the English smoothing. This work was funded by NSRF (Belgian Scientific Research Foundation) credits. Additional funds (for dating) were provided by the ASBL Parc Naturel Hautes FagnesEifel and the Ministère de la Région Wallonne. François De Vleeschouwer was supported by a FRIA fellowship.

\section{References}

Asmerom, Y., Jacobsen, S.B., 1993. The Pb isotopic evolution of the earth: inferences from river water suspended loads. Earth Planet. Sci. Lett. $115,245-256$.

Baron, S., Lavoie, M., Ploquin, A., Carignan, J., Pulido, M., De Beaulieu, J.-L., 2005. Record of metal workshops in peat deposits: history and environmental impact on the Mont Lozère Massif. France Environ. Sci. Technol. 39, 5131-5140.

Bastin, J., 1934. La Via Mansuerisca. L'Antiquité classique 3, 363-383.

Blaauw, M., Christen, J.A., 2005. Radiocarbon peat chronologies and environmental change. Appl. Statistics 54, 805-816.

Bollhöfer, A., Rosman, K.J.R., 2001. Isotopic source signatures for atmospheric lead: the northern hemisphere. Geochim. Cosmochim. Acta 65, 1727-1740.

Brännvall, M.-L., Bindler, R., Renberg, I., Emteryd, O., Billström, K., 1999. The medieval metal industry was the cradle of modern large-scale atmospheric lead pollution in northern Europe. Environ. Sci. Technol. 33, 4391-4395.

Bronk Ramsey, C., 2001. Development of the radiocarbon program OxCal. Radiocarbon 43, 355-363.

Buck, C.E., Cavanagh, W.G., Litton, C.D., 1996. The Bayesian Approach to Interpreting Archaeological Data. Wiley, Chichester.

Cauet, S., Weis, D., Herbosh, A., 1982. Genetic study of Belgian lead and zinc mineralizations in carbonate environments through lead isotopic geochemistry. Bull. BRGM Section II 4, 329-341.

Cauuet, B., 2005. Les mines d'or antiques d'Europe hors péninsule Ibérique. État des connaissances et travaux récents, Mines et métallurgies dans l'Antiquité. Etat des recherches - Dossier thématique, Pallas, 67, Toulouse, pp. 241-291.

Chevallier, R., 1972. Les voies romaines. Armand Colin, Paris.

Corbiau, M.H., 1981a. La Via Mansuerisca Etude archéologique du tracé et des structures. Archaeol. Belg. 235, 5-31.

Corbiau, M.H., 1981b. La Via Mansuerisca liaison routière entre Trèves et Maestricht? Les Etudes Classiques XLIX, 327-341.

Corbiau, M.H., 2005. Nouvelles recherches archéologiques pluridisciplinaires sur le parcours de la voie médiévale dite la Via Mansuerisca et découverte d'un véhicule dans la Fagne Rasquin à Waimes (Lg). Archaeol. Mediaevalis 28, 6-9.

Corbiau, M.H., 2006. L'organisation routière du Nord de la Gaule. Regards sur le territoire belge. Dossiers de l'Archéologie et sciences des origines $315,28-31$.

Dalemans, C., Streel, M., 1986. La Via Mansuerisca, enfouie dans la Fagne des Wez, est mérovingienne, pas romaine. Hautes Fagnes 180, 93-102.

Damblon, F., 1994. Les dépôts tourbeux et l'histoire de la végétation sur le plateau des Hautes Fagnes (Belgique). Ann. Soc. Géol. de Belg. 117 (fasc. 2), 259-276.

Dejonghe, L., 1998. Zinc-lead deposits of Belgium. Ore Geol. Rev. 12, 329-354.

Dejonghe, L., Ladeuze, F., 1993. Atlas des gisements plombo-zincifères du synclinorium de Verviers (Est de la Belgique). Geol. Surv. Belgium, Memoirs, 33.

De Vleeschouwer, F., 2007. Heavy metal records in peat. Archives of natural vs. anthropogenic influences. PhD Thesis, Univ. Liège.

De Vleeschouwer, F., Gerard, L., Goormaghtigh, C., Mattielli, N., Le Roux, G., Fagel, N., 2007. Atmospheric lead and heavy metal pollution records from a Belgian peat bog spanning the last two millennia: human impact on a regional to global scale. Sci. Total Environ. 377, 282-295.

De Vleeschouwer, F., van Vliët-Lanoé, B., Fagel, N., Richter, T., Boës, X., 2008. High resolution petrography on resin-impregnated Holocene peat columns containing tephras. Principle, applications and perspectives. In: International Global Tephra Studies: John Westgate and Andrei Sarna-Wojcicki Commemorative, vol. 178, pp. 54-67.

Dumont, J.-M., 1979. Première datation d'un tertre d'orpaillage en Ardenne. Glain et Salm, Haute Ardenne 10, 87-88.

Dumont, J.-M., 1980. Orpaillage celtique à l'époque de la Tène au Plateau des Tailles. Glain et Salm, Haute Ardenne 13, 42-45.

Durali-Mueller, S., Brey, G.P., Wigg-Wolf, D., Lahaye, Y., 2007. Roman lead mining in Germany: its origin and development through time 
deduced from lead isotope provenance studies. J. Archaeol. Sci. 34 (10), 1555-1567.

Elmaleh, A., Galy, A., Day, J.A., Marriner, N., Morhange, C., 2007. A heavy metals record from the ancient northern harbor of Tyre (Lebanon). Geophys. Res. Abstr. 9, 09415.

Galer, S.J.G., Abouchami, W., 1998. Practical applications of lead triple spiking correction of instrumental mass discrimination. Mineral. Mag. 62A, 491-492.

Gérard, L., 2004. Suivi des apports atmosphériques en plomb au cours de l'Holocène: Enregistrement dans des tourbières des Fagnes. Bachelor Thesis, Univ. Liège.

Gilot, E., 1977. Index général des dates Lv. Laboratoire du carbone 14 de Louvain/Louvain-la-Neuve. Studia Praehistorica Belgica 7. LiègeLeuven.

Goormaghtigh, C., 2005. Suivi des apports atmosphériques en métaux lourds durant la période Subatlantique (depuis 850 ans), dans un milieu continental pollué: enregistrement de deux tourbières des Hautes Fagnes (Belgique). Bachelor Thesis, Univ. Brussels.

Gotjé, W., van Wayjen, M.C.A., Van Geel, B., 1990. A palynological study of a Holocene deposit from Grand Bongard (Hautes Fagnes, Belgium). Geol Mijnbouw 69, 227-241.

Graillet, L., 1998. In: Graillet, L. (Ed.), De l'or en Ardenne. Liège, Belgique.

Grattan, J.P., Gilbertson, D.D., Hunt, C.O., 2007. The local and global dimensions of metalliferous pollution derived from a reconstruction of an eight thousand years record of copper smelting and mining at a desert-mountain frontier in southern Jordan.J.Archaeol.Sci.34,83-110.

Grousset, F.E., Quetel, C.R., Thomas, B., Buatmenard, P., Donard, O.F.X., Bucher, A., 1994. Transient $\mathrm{Pb}$ isotopic signatures in the westernEuropean atmosphere. Environ. Sci. Technol. 28, 1605-1608.

Halleux, R., 2005. La fabrication du laiton. In: Toussaint, J. (Ed.), Art du laiton - dinanderie. Société archéologique de Namur, pp. 31-36.

Hemming, S.R., McLennan, S.M., 2001. Pb isotope compositions of modern deep sea turbidites. Earth Planet. Sci. Lett. 184, 489-503.

Jones, J.M., Hao, J., 1993. Ombrotrophic peat as a medium for historical monitoring of heavy metal pollution. Environ. Geochem. Health 15, 67-74.

Kempter, H., 1996. Der Verlauf des anthropogenen elementeintrags in Regenwassermoore des westlichen Mitteleuropas während des jüngeren Holozäns. Paläoklimaforschung 26, 309.

Kempter, H., Frenzel, B., 1999. The local nature of anthropogenic emission sources on the elemental content of nearby ombrotrophic peat bogs, Vulkaneifel, Germany. Sci. Total Environ. 241, 117-128.

Ladeuze, F., Dejonghe, L., Pauquet, F., 1991. La Vieille-Montagne, l'exploitation minière et la métallurgie du zinc dans l'ancien duché de Limbourg. Bulletin trimestriel du Crédit communal, 178.

Le Roux, G., Véron, A., Morhange, C., 2004b. Geochemical evidences of early anthropogenic activity in harbour sediments from Sidon. Archaeol. History of Lebanon 18, 115-119.

Le Roux, G., Weiss, D., Grattan, J., Givelet, N., Krachler, M., Cheburkin, A. Rausch, N., Kober, B., Shotyk, W., 2004a. Identifying the sources and timing of ancient and medieval atmospheric lead pollution in England using a peat profile from Lindow bog, Manchester. J. Environ. Monitor. $6,502-510$.

Lewalle, J., 1963. La Via Mansuerisca. Chronique Archéologique du Pays de Liège, 102-113.

Livett, E.A., Lee, J.A., Tallis, J.H., 1979. Lead, zinc and copper analysis of British blanket peats. J. Ecol. 67, 865-891.

Martínez-Cortizas, A., García-Rodeja, E., Pontevedra-Pombal, X., Nóvoa Muñoz, J., Weiss, D., Cheburkin, A.K., 2002. Atmospheric Pb deposition in Spain during the last 4600 years recorded by two ombrotrophic peat bogs and implications for the use of peat as archives. Sci. Total Environ. 292, 33-44.

Martínez-Cortizas, A., Pontevedra-Pombal, X., Nóvoa Muñoz, J.C., GarcíaRodeja, E., 1997. Four thousand years of atmospheric Pb, Cd and $\mathrm{Zn}$ deposition recorded by the ombrotrophic peat bog of Penido Vello (Northwestern Spain). Water Air Soil Pollut. 100, 387-403.

Mertens, J., 1957. Les routes romaines de la Belgique. Archaeol. Belg., 33.

Mighall, T.M., Abrahams, P.W., Grattan, J.P., Hayes, D., Timberlake, S., Forsyth, S., 2002. Geochemical evidence for atmospheric pollution derived from prehistoric copper mining at Copa Hill, Cwmywtwyth, mid-Wales. Sci Total Environ. 292, 69-80.

Mighall, T.M., Timberlake, S., Jenkins, D.A., Grattan, J.P., 2006. Using bog archives to reconstruct palaeopollution and vegetation change during the late Holocene. In: Martini, I.P., Martínez-Cortízas, A., Chesworth, W. (Eds.), Peatlands Evolution and Records of Environmental and Climate Changes. Developments in Earth Surface Processes 9. Elsevier Amsterdam, The Netherlands, pp. 409-430.

Millot, R., Allègre, C.-J., Gaillardet, J., Roy, S., 2004. Lead isotopic systematics of major river sediments: a new estimate of the $\mathrm{Pb}$ isotopic composition of the Upper Continental Crust. Chem. Geol. 203, 75-90.

Nekrassoff, S., 1993. La via Mansuerisca, route romaine des Fagnes Le poids de la tradition. Hautes Fagnes 209, 6-11.

Nieminen, T.M., Ukonmaanaho, L., Shotyk, W., 2002. Enrichments of $\mathrm{Cu}$, $\mathrm{Ni}, \mathrm{Zn}, \mathrm{Pb}$ and $\mathrm{As}$ in an ombrotrophic peat bog near a $\mathrm{Cu}-\mathrm{Ni}$ smelter in Southwest Finland. Sci. Total Environ. 292, 81-89.

Novak, M., Emmanuel, S., Vile, M.A., Erel, Y., Véron, A., Paces, T., Kelman Wieder, R., Vanecek, M., Marketa, S., Brizova, E., Hovorka, J., 2003. Origin of lead in eight Central European peat bogs determined from isotope ratios, strengths, and operation times of regional pollution sources. Environ. Sci. Technol. 37, 437-445.

Nriagu, J.O., 1996. A history of global metal pollution. Science 272, 223224.

Pasteels, P., Netels, V., Dejonghe, L., Deutsch, S., 1980. La composition isotopique du plomb des gisements belges. Implications sur les plans génétique et économique. (Note préliminaire). Bull. Société Belge Géol. 89, 123-126.

Permingeat, F., Rouveyrol, P., De Béthune, P., Bintz, J., Pietzner, H., Scherp, A., Rée, C., Schottler, W., 1964. Carte des gîtes minéraux, 1/320000, Ardennes. BRGM.

Persch, F., 1950. Zur postglazialen Wald- und Moorentwicklung im Hohen Venn. Decheniana 104, 81-93.

Plini the Elder, 1953. Histoires Naturelles, vol. 34. Edition Les Belles Lettres, Paris. French translation (chapter 34-2).

Remy, H., 1981. Monographie archéologique Commune de Vielsalm. In: Glain et Salm, Haute Ardenne, Vielsalm, vol. 14, pp. 44-69.

Shotyk, W., 1988. Review of the inorganic geochemistry of peats and peatland waters. Earth-Sci. Rev. 25, 95-176.

Shotyk, W., 2002. The chronology of anthropogenic, atmospheric $\mathrm{Pb}$ deposition recorded by peat cores in three minerogenic peat deposits from Switzerland. Sci. Total Environ. 292, 19-31.

Shotyk, W., Blaser, P., Grünig, A., Cheburkin, A.K., 2000. A new approach for quantifying cumulative, anthropogenic, atmospheric lead deposition using peat cores from bogs: $\mathrm{Pb}$ in eight Swiss peat bog profiles. Sci. Total Environ. 249, 281-295.

Shotyk, W., Goodsite, M.E., Roos-Barraclough, F., Frei, R., Heinemeier, J., Asmund, G., Lohse, C., Hansen, T.S., 2003. Anthropogenic contributions to atmospheric $\mathrm{Hg}, \mathrm{Pb}$ and As accumulation recorded by peat cores from southern Greenland and Denmark dated using the ${ }^{14} \mathrm{C}$ bomb pulse curve. Geochim. Cosmochim. Acta 67, 3991-4011.

Shotyk, W., Weiss, D., Appleby, P.G., Cheburkin, A.K., Frei, R., Gloor, M., Kramers, J.D., Reese, S., Knaap, V.D., 1998. History of atmospheric lead deposition since $12,370{ }^{14} \mathrm{C}$ yr BP from a peat bog, Jura mountains, Switzerland. Science 281, 1635-1640.

Sonke, J.E., Hoogewerff, J.A., van der Laan, S.A., Vangronsveld, J., 2002. A chemical and mineralogical reconstruction of $\mathrm{Zn}$ smelter emissions in the Kempen region (Belgium), based on organic pool sediment cores. Sci. Total Environ. 292, 101-119.

Sonke, J.E., Sivry, Y., Viers, J., Freydier, R., Dejonghe, L., André, L., Aggarwal, J.K., Fontan, F., Dupré, B., 2008. Historical variations in the isotopic composition of atmospheric zinc deposition from a zinc smelter. Chem. Geol. 252 (3-4), 145-157. doi: 0.1016/j.chemgeo.2008.02.006.

Speranza, A., van der Plicht, J., Van Geel, B., 2000. Improving the time control of the Subboreal/Subatlantic transition in a Czech peat sequence by ${ }^{14} \mathrm{C}$ wiggle-matching. Quatern. Sci. Rev. 19, 1589-1604.

Sutherland, C.H.V., 1967. In: Sutherland, C.H.V., Carson, R.A.G. (Eds.), Diocletian to Maximinus. Roman Imperial Coinage, vol. VI. Spink, London.

Wastiaux, C., Schumacker, R., 2003. Topographie de surface et de subsurface des zones tourbeuses des réserves naturelles domaniales des Hautes Fagnes. Convention C60 entre le Ministère de la Région Wallonne, Direction générale des Ressources naturelles et de l'Environnement, et l'Université de Liège.

Weis, D., Kieffer, B., Maerschalk, C., Barling, J., De Jong, J., Williams, G., Hanano, D., Pretorius, W., Mattielli, N., Scoates, J.S., Goolaerts, A., Friedman, R., Mahoney, J.B., 2006. High-precision isotopic characterization of USGS reference materials by TIMS and MC-ICPMS. Geochem. Geophys. Geosyst. 7. doi:10.1029/2006GC001283.

Weiss, D.J., Rausch, N., Mason, T.F.D., Coles, B.J., Wilkinson, J.J., Ukonmaanaho, L., Arnold, T., Nieminen, T.M., 2007. Atmospheric deposition and isotope biogeochemistry of zinc in ombrotrophic peat. Geochim. Cosmochim. Acta 71, 3498-3517.

West, S., Charman, D.J., Grattan, J.P., Cheburkin, A.K., 1997. Heavy metals in Holocene peats from South West England: detecting mining impacts and atmospheric pollution. Water Air Soil Pollut. 100, 343353.

White, W.M., Albarède, F., Télouk, P., 2000. High-precision analysis of $\mathrm{Pb}$ isotope ratios by multi-collector ICP-MS. Chem. Geol. 167, 257-270. 